\title{
Dissecting the Crosstalk between Endothelial Mitochondrial Damage, Vascular Inflammation, and Neurodegeneration in Cerebral Amyloid Angiopathy and Alzheimer's Disease
}

\author{
Rebecca M. Parodi-Rullán ${ }^{1}\left(\mathbb{D}\right.$, Sabzali Javadov ${ }^{2}$ (D) and Silvia Fossati ${ }^{1, *(D)}$ \\ 1 Alzheimer's Center at Temple, Lewis Katz School of Medicine, Temple University, \\ Philadelphia, PA 19140, USA; rebecca.parodi-rullan@temple.edu \\ 2 Department of Physiology, University of Puerto Rico School of Medicine, San Juan, PR 00921, USA; \\ sabzali.javadov@upr.edu \\ * Correspondence: silvia.fossati@temple.edu; Tel.: +1-215-707-6046
}

\section{check for} updates

Citation: Parodi-Rullán, R.M.; Javadov, S.; Fossati, S. Dissecting the Crosstalk between Endothelial Mitochondrial Damage, Vascular Inflammation, and Neuro degeneration in Cerebral Amyloid Angiopathy and Alzheimer's Disease. Cells 2021, 10, 2903. https://doi.org/ $10.3390 /$ cells10112903

Academic Editor:

Kai-Christian Sonntag

Received: 15 September 2021

Accepted: 24 October 2021

Published: 27 October 2021

Publisher's Note: MDPI stays neutral with regard to jurisdictional claims in published maps and institutional affiliations.

Copyright: (c) 2021 by the authors. Licensee MDPI, Basel, Switzerland. This article is an open access article distributed under the terms and conditions of the Creative Commons Attribution (CC BY) license (https:/ / creativecommons.org/licenses/by/ $4.0 /)$.

\begin{abstract}
Alzheimer's disease (AD) is the most prevalent cause of dementia and is pathologically characterized by the presence of parenchymal senile plaques composed of amyloid $\beta(\mathrm{A} \beta)$ and intraneuronal neurofibrillary tangles of hyperphosphorylated tau protein. The accumulation of A $\beta$ also occurs within the cerebral vasculature in over $80 \%$ of AD patients and in non-demented individuals, a condition called cerebral amyloid angiopathy (CAA). The development of CAA is associated with neurovascular dysfunction, blood-brain barrier (BBB) leakage, and persistent vascular- and neuro-inflammation, eventually leading to neurodegeneration. Although pathologically $\mathrm{AD}$ and CAA are well characterized diseases, the chronology of molecular changes that lead to their development is still unclear. Substantial evidence demonstrates defects in mitochondrial function in various cells of the neurovascular unit as well as in the brain parenchyma during the early stages of AD and CAA. Dysfunctional mitochondria release danger-associated molecular patterns (DAMPs) that activate a wide range of inflammatory pathways. In this review, we gather evidence to postulate a crucial role of the mitochondria, specifically of cerebral endothelial cells, as sensors and initiators of A $\beta$-induced vascular inflammation. The activated vasculature recruits circulating immune cells into the brain parenchyma, leading to the development of neuroinflammation and neurodegeneration in $\mathrm{AD}$ and CAA.
\end{abstract}

Keywords: mitochondria; Alzheimer's disease; cerebral amyloid angiopathy; inflammation; neurodegeneration; amyloid; endothelial cells

\section{Introduction}

With an increase in life expectancy, there has been an increase in the incidence of agerelated diseases, particularly Alzheimer's disease (AD) which is the most prevalent cause of dementia, representing around $60-80 \%$ of all dementia cases. Approximately 6.2 million Americans are currently living with AD, and due to the increase in the aging population, it is expected that this number will grow to 13.8 million by 2060 [1]. Currently, there is no effective therapy for AD. In 2021, after nearly twenty years of attempts to develop new therapeutic strategies, aducanumab, a human monoclonal antibody that selectively targets aggregated amyloid- $\beta(\mathrm{A} \beta)$, has been approved by the FDA (through the accelerated approval pathway) for treatment of patients with AD [2]. However, the therapeutic effectiveness of aducanumab is still debated by many research groups [2-4]. The high prevalence of AD among aged individuals and lack of effective therapy denotes the importance of developing new therapeutics, and to do so we need to have a better understanding of the complexity of the disease.

Clinical manifestations of AD include progressive cognitive impairment, which develops after years of asymptomatic pathological and molecular changes. Pathologically, 
$\mathrm{AD}$ is characterized by the presence of extracellular senile plaques of aggregated $\mathrm{A} \beta$ and intraneuronal neurofibrillary tangles of hyperphosphorylated tau protein [5]. AD is a multifactorial disease and vascular dysfunction is one of the most common co-pathologies that may also be an important contributor to disease progression [6,7]. Indeed, in over $80 \%$ of $\mathrm{AD}$ patients, and to a smaller extent in non-demented individuals, $\mathrm{A} \beta$ is also found around cerebral vessels, a condition known as cerebral amyloid angiopathy (CAA) [8]. The vascular accumulation of $A \beta$ occurs mostly in cortical and leptomeningeal arteries and capillaries and is often associated with cerebral microhemorrhages, increasing blood-brain barrier (BBB) permeability, and inflammation $[9,10]$. However, it is important to note that CAA is not exclusive to amyloidosis due to $A \beta[11,12]$.

The cerebrovascular accumulation of $A \beta$ results in neurovascular dysfunction, neuroinflammation, and progression of the neurodegenerative process. Elevated levels of IL-6, $\mathrm{TNF} \alpha$, and IL- $\beta \beta$ have been detected in animal models of amyloidosis, such as Tg2576 and $3 \times \mathrm{Tg}$ mice, and in the cerebrospinal fluid (CSF) of AD patients [13,14], indicating the presence of sustained inflammation [15] that accompanies AD pathology. In particular, cerebrovascular inflammation has been shown in animal models of amyloidosis as well as in post-mortem human brains $[16,17]$. These perivascular inflammatory processes may precede and stimulate parenchymal plaque deposition [17]. Indeed, increasing evidence suggests that vascular dysfunction can occur before classical AD pathology [18-21]. Vascular inflammation leads to immune cell extravasation into the brain parenchyma and widespread neuroinflammation, which has been shown to positively correlate with the levels of $\mathrm{A} \beta$ in mouse models of amyloidosis and in $\mathrm{AD}$ patients [22-24]. Altogether, recent studies indicate the importance of understanding key vascular events that contribute to the development of neuroinflammation and neurodegeneration.

Amongst the vascular mechanisms that may contribute to neurodegeneration, alterations in the metabolism and function of cerebrovascular mitochondria play a crucial role in A $\beta$-induced dysfunction of endothelial cells (EC), BBB permeability, and inflammation [25-28]. Therefore, the preservation of mitochondrial function is an attractive strategy towards the prevention of age-associated neurodegenerative diseases such as $\mathrm{AD}$ and CAA [29]. In this review, we summarize and discuss previous studies investigating the role of cerebrovascular mitochondria, particularly EC mitochondria, as mediators of neuroinflammation in CAA and AD. Additionally, we will focus on the role of A $\beta$-induced mitochondrial dysfunction in ECs, how this may initiate the inflammatory process in the neurovascular unit, and discuss the pathways that may lead to neurodegeneration.

\section{Endothelial Cells and the Neurovascular Unit}

The neurovascular unit (NVU) is composed of ECs lining the vascular lumen, smooth muscle cells (SMC) present in the arteries and veins, pericytes, and astrocytes. Cerebrovascular cells are also connected with other brain cells such as neurons and microglia and thus, the NVU provides the structural and functional relationship between the brain and cerebral vasculature. Particularly, it participates in the maintenance and regulation of cerebral circulation, vascular permeability through the BBB, and mediation of brain inflammatory pathways. Therefore, NVU dysfunction is a prominent and early feature in the AD brain [30-34]. The BBB serves as a barrier for the movement of molecules from the blood to the cerebral parenchyma. Its unique structure permits the regulation of the passage of molecules such as peptides, toxins, nutrients, and metabolites between the blood and the brain. This function of the BBB is primarily mediated by cerebrovascular ECs, which differ from other ECs due to the lack of fenestrations, low pinocytic activity, the expression of tight junctions (TJs, one of the characteristics of the $\mathrm{BBB}$ ), and high mitochondrial content $[35,36]$. Indeed, the high mitochondrial mass in comparison to peripheral ECs indicates the significant role played by the mitochondria in the metabolism and function of cerebral ECs [37]. Notably, mitochondrial content was found to be reduced in the brains of patients with $\mathrm{AD}$ [38]. Mitochondria have been shown to play a crucial role 
in the downstream pathways mediating EC damage during AD and CAA [39], vascular inflammation, and neurodegeneration [40-44].

\section{Failure of A $\beta$ Clearance and CAA Development}

Sequential cleavage of the amyloid precursor protein (APP) by $\beta$-secretase and $\gamma$ secretase generates $A \beta$ peptides, which are released from neurons and other brain cells into the brain parenchyma. A $\beta$ peptides aggregate to form oligomers, fibrils, and eventually the amyloid plaques observed in AD brains. The main $\mathrm{A} \beta$ peptides found in the brain parenchyma and around the cerebral vessels are $A \beta 40$ and $A \beta 42$, although the processing of APP leads to the generation of multiple other $A \beta$ fragments varying in length and aggregation profile [28,45]. It is speculated that the accumulation of $A \beta$ in the brain and around cerebral vessels may be due to increased APP cleavage, A $\beta$ aggregation, as well as decreased $A \beta$ clearance, or combinations of these mechanisms. Due to the lack of conventional lymphatic vessels in the brain, clearance of $A \beta$ from the parenchyma into the lymphatic system is thought to occur through intramural periarterial drainage (IPAD) [46-48] and/or through the glymphatic system [49-51]. Clearance of metabolites through IPAD occurs primarily along the basement membranes of cerebral capillaries and arteries. The precise mechanism of the movement of molecules and peptides, including $A \beta$, along the basement membrane of the cerebral vasculature, remains unclear. Several mechanisms such as arterial pulsations and vascular smooth muscle cell contractility have been proposed $[52,53]$. The glymphatic system hypothesis is based on the observation that tracers injected into the subarachnoid CSF readily flow into the brain along the outside of the penetrating blood vessels. This suggests that CSF flows into the brain tissue along para-arterial spaces and exits via a para-venous route, aided by astrocytic end-feet through aquaporin $4[49,54]$. The meningeal lymphatic vessels might provide another important clearance route for brain products, which is recently gaining relevance in neurodegenerative disorders such as AD [55,56].

Thus, multiple routes participate in cerebral clearance of waste products including $A \beta$. These pathways may act in parallel or in a complementary fashion to maintain brain homeostasis [57]. Most importantly, failure of $A \beta$ clearance by one or multiple mechanisms may lead to $A \beta$ deposition along the cerebral vasculature (CAA), leading to NVU dysfunction. The accumulation of $A \beta$ around the cerebral vasculature occurs in a progressive fashion: first, $A \beta$ surrounds the vessels in the adventitia and tunica media, provoking vascular SMC damage and eventually death. Later, as the accumulation progresses, the tunica media is replaced by $A \beta$ fibrils which later may lead to EC death, BBB breakdown, and microhemorrhages [58]. Indeed, early studies report that in human $A D$ brains, the accumulation of $A \beta$ fibrils in cerebral vessels provokes EC degeneration and reduction in vessel size [59]. This vascular dysfunction, in turn, is associated with cerebral hypoperfusion, neuroinflammation, parenchymal $\mathrm{A} \beta$ accumulation, plaque formation, and $A D$ progression. Therefore, it is important to understand the effects of $A \beta$ accumulation on the cerebral vasculature and its role in the progression of the neurodegenerative process in the brain of patients with $\mathrm{AD}$ and CAA.

\section{Activation of Endothelial Inflammatory Pathways by $A \beta$}

Inflammatory pathways may be activated through pattern recognition receptors (PRRs) such as membrane-bound toll-like receptors (TLRs) and C-type lectin receptors (CLRs), as well as cytoplasmic NOD-like receptors (NLRs) and retinoic acid inducible gene I (RIG-I)-like receptors (RLRs). PRRs are expressed by immune and non-immune cells such as fibroblasts, epithelial cells, and ECs. They are responsible for the detection of pathogen-associated molecular patterns (PAMPs) and danger-associated molecular patterns (DAMPs). The PAMPs are foreign molecules derived from viruses and bacteria whereas DAMPs are danger signals originating from the organism and are associated with cellular damage [60]. In addition to the PRRs, DAMPs can also activate non-PRR such as the receptor for advanced glycation end products (RAGE) and triggering receptors 
expressed on myeloid cells (TREMs) [60]. The activation of PRRs and non-PRRs by DAMPs is also referred to as sterile inflammation, due to the absence of pathogens. Interestingly, many of the DAMPs associated with sterile inflammation are of mitochondrial origin, highlighting the crucial role of mitochondria in neuroinflammation [26].

In ECs, $A \beta$ transport across the plasma membrane is regulated by the low-density lipoprotein receptor-related protein 1 (LRP1) to deliver the peptide from the brain parenchyma to the blood. LRP1-mediated endocytosis regulates cellular $A \beta$ uptake by binding to $A \beta$ either directly or indirectly through its co-receptors or ligands. Transport of $A \beta$ from the periphery to the brain is mediated by RAGE [61,62]. RAGE is a receptor of the immunoglobulin superfamily that is found on the luminal side of ECs of the BBB. RAGE-mediated transport of $A \beta$ across the $B B B$ may lead to $A \beta$ deposition in the brain parenchyma and, in addition, induce inflammatory responses [62]. The pro-inflammatory effects of the A $\beta-$ RAGE interaction have been extensively studied in various cell and animal models [62-64].

Activation of inflammatory responses by ECs is characterized by the expression of cellular adhesion molecules (CAMs), such as vascular cell adhesion molecule-1 (VCAM-1), intercellular adhesion molecule-1 (ICAM-1), and E-selectin as well as disruption of the $\mathrm{BBB}$, and release of pro-inflammatory cytokines. The presence of DAMPs has been shown to induce a pro-inflammatory state in ECs that leads to the recruitment of immune cells, triggering the further release of pro-inflammatory cytokines and activation of resident microglial cells [24]. One of the most important mediators of the inflammatory state in ECs is the NLR family pyrin domain containing 3 (NLRP3). Elevated levels of NLRP3 have been observed in human AD brains [65] and animal models of amyloidosis [66]. Cytosolic NLRP3 can be activated indirectly through its capabilities of sensing intracellular danger associated molecules, such as mitochondrial DAMPs, or directly by the endothelial CD36 receptor upon A $\beta$ binding $[67,68]$. Activation of NLRP3 and the recruitment of the adaptor protein, apoptosis-associated speck-like protein containing a caspase recruitment domain (ASC), induces the catalytic cleavage of pro-caspase- 1 to active caspase- 1 . Active caspase- 1 , in turn, cleaves pro-inflammatory cytokines pro-IL-1 $\beta$, pro-IL-18, and gasmerdin $\mathrm{D}$, producing their active forms. Gasmerdin D forms non-selective pores in the plasma membrane to facilitate the release of cytokines, and thus activates pyroptosis, a form of inflammatory cell death $[60,69,70]$. It has been suggested that NLRP3 can also activate the nuclear factor kappa-light-chain-enhancer of activated B cells (NFkB) which, in turn, increases the transcription of pro-inflammatory cytokines [71] and thereby initiates a positive feedback loop to further stimulate the inflammatory response. Interestingly, NFKB is also capable of downregulating the endothelial nitric oxide synthase (eNOS), thereby decreasing NO bioavailability and vascular relaxation [72].

\section{Pathological Consequences of $A \beta$ on Endothelial Mitochondria}

Cerebrovascular ECs are the gatekeepers of brain health through the maintenance of the BBB and regulation of movement of ions and molecules across the blood-brain interface. Due to their important role in brain cell health, alterations of mitochondrial structure and function in cerebrovascular ECs induce cell dysfunction, loss of BBB integrity, and inflammation, eventually leading to cell death [27,39,73-75]. Cerebrovascular ECs contain more mitochondria than any other EC in the body. Mitochondria account for $8-11 \%$ of cytoplasmic volume in brain ECs, compared to only $2-5 \%$ in non-cerebrovascular ECs [35,37].

In $\mathrm{CAA}, \mathrm{A} \beta$ can induce $\mathrm{EC}$ apoptosis through the direct binding and activation of the TRAIL death receptors (DR) DR4 and DR5 [76]. These effects appear to be preferentially mediated by oligomeric and/or protofibrillar amyloid species, while species that have fast aggregation dynamics and quickly form fibrils, as well as $\mathrm{A} \beta$ peptides that remain mostly monomeric, fail to induce EC apoptosis. Fibrillar species, however, are involved in other EC damage pathways, such as increases of BBB permeability [28]. The activation of the TRAIL DRs by $A \beta$ oligomers and protofibrils triggers the extrinsic apoptotic pathway, leading 
to cleavage of caspase 8 to its active form, cleavage of $\mathrm{BH}$-interacting domain death agonist (BID), and release of cytochrome $\mathrm{C}(\mathrm{CytC})$ from mitochondria with subsequent activation of the intrinsic apoptotic pathway. Indeed, loss of mitochondrial membrane potential, a key event preceding $\mathrm{CytC}$ release, was observed in the presence of $\mathrm{A} \beta$, along with the release of reactive oxygen species (ROS) [27,39,77-79]. Interestingly, the CD36 receptor appears to be involved in the progression of CAA and loss of TJ proteins in Tg2576 mice, a model characterized by amyloid parenchymal deposition as well as CAA, through NADPH oxidase-mediated increases in ROS [80,81], however the contribution of CD36 to $\mathrm{A} \beta$-induced mitochondrial dysfunction in ECs is unclear.

Additionally, in animal models of amyloidosis, it has been shown that the mitochondrial permeability transition pore $(\mathrm{mPTP})$ is an important contributor to mitochondrial dysfunction, neuronal death, and cognitive dysfunction in AD models [82], but only a few studies have investigated the potential effects of mPTP in mediating the detrimental effects $\mathrm{A} \beta$ on cerebrovascular ECs [83]. In the following sections, we will address the possible contribution of the $\mathrm{mPTP}$, mitochondrial ROS (mtROS), and mitochondrial DNA (mtDNA) to inflammation during $\mathrm{A} \beta$ pathology.

\section{Mitochondrial DAMPs as Initiators of Inflammation}

The mitochondrion is thought to have originated from an endosymbiotic uptake of an $\alpha$-proteobacteria [84]. The immune system serves as a protective wall against cellular damage and pathogens; therefore, it is of no surprise that mitochondrial fragments may trigger an immune response. In turn, activators of inflammatory pathways also trigger mitochondrial damage such as mtROS production and loss of mitochondrial membrane potential [85], potentially resulting in a vicious cycle between mitochondrial dysfunction and inflammation. In addition, inflammatory mediators could also amplify mitochondrial dysfunction, as NLRP3-mediated Caspase-1 activation was shown to induce mtROS production, loss of mitochondrial membrane potential, and mitochondrial membrane permeabilization, resulting in the release of mitochondrial DAMPs in bone-marrow-derived macrophages (BMDM) [86]. Several mitochondrial components have been identified as DAMPs (Figure 1). In this section, we will attempt to highlight the part they play in innate immunity and whether their role has been identified in cerebral ECs in the context of AD and CAA.

\subsection{Mitochondrial ROS}

Accumulation of ROS in cells can occur due to increased ROS production in the cytosol (NAD(P)H oxidases) and mitochondria (electron transport chain (ETC), tricarboxylic acid (TCA) cycle, monoamine oxidases, etc.), and/or decreased activity of antioxidant enzymes (superoxide dismutase (SOD), catalase, peroxidase, etc.) and systems (glutathione, tocopherol, thioredoxin, ascorbic acid, etc.). Mitochondria are the major source of ROS, with over 10 different sites of ROS production [87]. In the inner mitochondrial membrane (IMM), electrons are moved across the ETC complexes accompanied by oxygen consumption. The proton gradient generated by ETC across the IMM stimulates ATP production through oxidative phosphorylation (OXPHOS). Mitochondrial ROS production increases in dysfunctional mitochondria as a result of downregulation of ETC and OXPHOS. Decreased activity of ETC complexes, particularly complexes I and III, stimulates excessive mtROS production due to increased electron leakage by these complexes generating superoxide anion $\left(\mathrm{O}_{2}{ }^{\bullet-}\right)$ [88]. The superoxide anion is converted to $\mathrm{H}_{2} \mathrm{O}_{2}$ and produces other oxygen radicals through Fenton reactions that are collectively known as ROS. Although production of mtROS occurs under normal physiological conditions, it is normally balanced by the antioxidant defense that includes SOD, catalase, peroxidase, thioredoxin, and glutathione systems. 


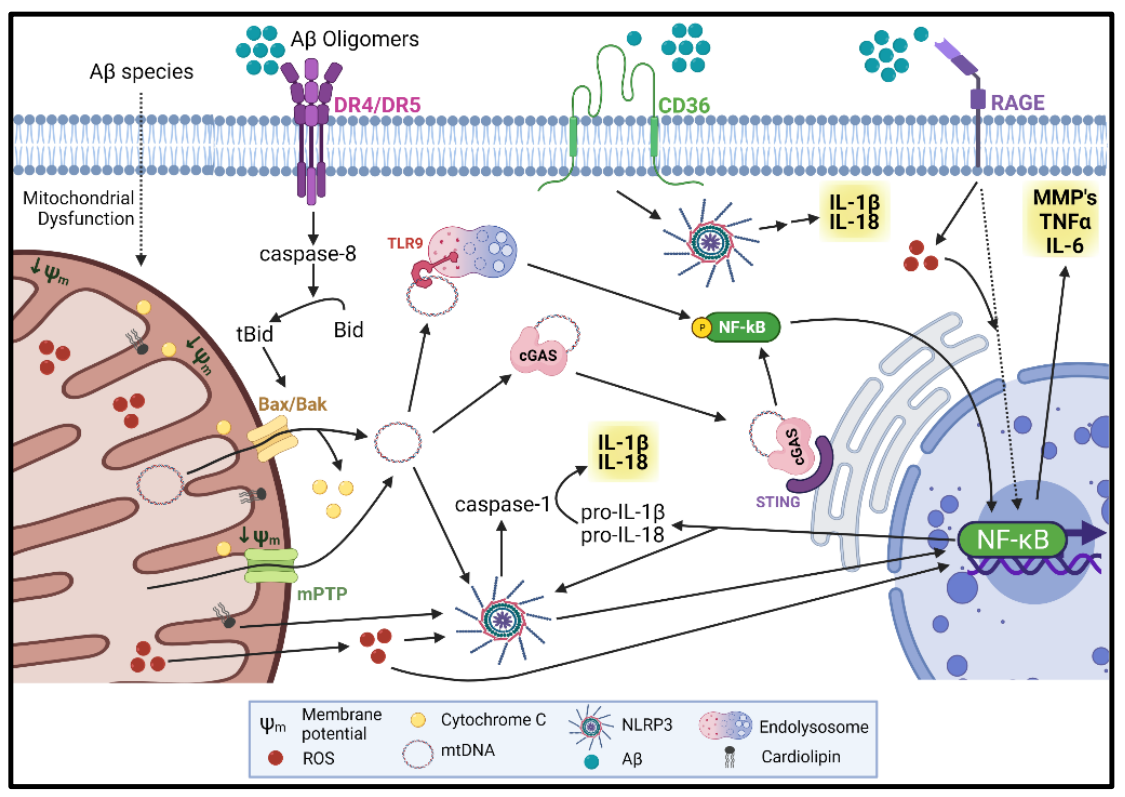

Figure 1. A $\beta$ induces the release of mitochondrial DAMPs in cerebral endothelial cells (ECs) inducing vascular activation. Mitochondrial dysfunction is induced by $\mathrm{A} \beta$, at least in part, through the binding and activation of TRAIL Death Receptors (DRs) and activation of the extrinsic and intrinsic apoptotic pathway. Amyloid $\beta$ has been shown to induce loss of mitochondrial membrane potential ( $\Psi \mathrm{m})$, increase in the generation of mitochondrial reactive oxygen species (mtROS), and permeabilization of mitochondrial membranes leading to the release of cytochrome $\mathrm{C}$ and mitochondrial DNA (mtDNA) into the cytoplasm of endothelial cells. The increase of mtROS leads to the activation of the NLRP3 inflammasome, activation of caspase- 1 and $N_{K} \times B$, resulting in the release of IL-1 $\beta$ and IL-18. Permeabilization of the inner mitochondrial membrane (IMM) and outer mitochondrial membrane (OMM) lead to the release of mtDNA to the cytoplasm. The presence of double stranded DNA (dsDNA) activates the NLRP3 inflammasome, toll-like receptor 9 (TLR9) on the endolysosomal compartment, and the cGAS/STING pathway on the cytosol and endoplasmic reticulum (ER) membrane, which lead to the activation of NFKB and upregulation of more pro-inflammatory cytokines. Amyloid $\beta$ can also activate the NLRP3 inflammasome by binding to the CD36 membrane receptor, or increase the production of ROS through the RAGE receptor. The exponential increase in pro-inflammatory cytokines leads to blood-brain barrier (BBB) disruption, through activation of matrix metalloproteinases (MMPs), downregulation of tight junction (TJ) proteins, EC activation, and expression of cell adhesion molecules. Figure created with BioRender.com.

Increased generation of ROS has been implicated in several diseases, including $\mathrm{AD}$ and CAA. A $\beta$ has been shown to increase mtROS production in neurons $[27,78]$ and cerebral ECs [27]. High ROS levels were observed in Tg2576 mice [89], along with a reduction in cerebral blood flow (CBF) [90]. Likewise, high ROS levels were found in the cerebral vasculature of the $3 \times \mathrm{Tg}$ mice, that develop amyloidosis and tauopathy [13]. In a mouse model expressing the human APP with the Swedish and Indiana mutations [91], downregulation of SOD2, a mitochondrial-matrix localized SOD, promoted vascular amyloidosis but not parenchymal amyloid deposition [43]. In contrast, SOD2 overexpression, as expected, was able to increase CBF, thereby reducing vascular dysfunction in Tg2576 mice [90]. Altogether, these studies demonstrate a crucial role of mtROS in the development of $\mathrm{AD}$ and CAA. Although the generation of ROS can be enhanced by upregulation of nonmitochondrial (cytoplasmic) sites such as NADPH oxidases, here, we will focus on the role of mtROS in vascular inflammation and neurodegeneration.

Substantial evidence has stipulated that $\mathrm{A} \beta$ can induce mtROS accumulation and EC inflammation $[13,27,43,78]$, however, the mechanism underlying the effects of $A \beta$ on cerebral EC mitochondria remains unclear. $A \beta$ may induce mtROS generation as a result 
of inhibition of ETC complexes [78], by modulation of downstream pathways after its binding to cell surface receptors, or through downregulation of antioxidant systems [43]. As mentioned above, $\mathrm{A} \beta$ has been shown to bind to and activate RAGE [92], leading to increased RAGE expression [64,93], ROS generation, and activation of the transcription factor NFKB [43,94-96], a key regulator of pro-IL-1 $\beta$, pro-IL18, and NLRP3 expression [25].

ROS are involved in NLRP3-mediated neuroinflammation induced by oligomeric $\mathrm{A} \beta$ in microglia [97], and polychlorinated biphenyls (PCB) 118-induced pyroptosis in ECs [98]. In rat brain ECs, an increase of superoxide induced the release of TNF $\alpha$ and A $\beta$ [15]. Similarly, ROS production was associated with the release of vascular IL-6, which was attenuated by the presence of a ROS scavenger in 3xTg mice [13], highlighting the role of ROS as mediators of vascular inflammation. Additionally, in BMDMs, attenuation of mtROS with mito-TEMPO, a mitochondria-targeted antioxidant, reduced caspase-1 activation and the release of IL-1 $\beta$ and IL18 in response to lipopolysaccharide (LPS) and ATP; two activators of the NLRP3 inflammasome [99]. Thus, accumulating evidence suggests that excessive ROS in ECs induces the activation of an inflammatory response and the NLRP3 inflammasome plays an important role in mediating the effects of ROS. In the context of $C A A$ and $A D, A \beta$ may be the culprit of such an increase in mtROS generation.

\subsection{Mitochondrial Permeability Transition Pore}

The MPTP is a pathological pore that forms across the IMM in response to various pathological stimuli associated with matrix $\mathrm{Ca}^{2+}$ overload, elevated mtROS, and loss of mitochondrial membrane potential. The $\mathrm{MPTP}$ is a non-selective pore that allows the passage of solutes up to $1.5 \mathrm{kDa}$ across the IMM. Under physiological conditions, the IMM is impermeable and the transport of ions and other solutes through the membrane is regulated by membrane transporters and other exchange mechanisms. Therefore, the formation of the MPTP causes mitochondrial swelling due to increased colloid osmotic pressure in the mitochondrial matrix which, in turn, leads to rupture of the outer mitochondrial membrane (OMM). As a result, apoptotic proteins such as CytC are released from the intermembrane space of mitochondria to the cytosol. Although the formation of the MPTP is well documented and has been observed under electrophysiological preparations [100], the molecular identity of the pore is unknown. Ironically, inhibition of the mPTP would be an ideal target for various diseases including myocardial infarction [101,102], cerebral ischemia [103,104], and AD [105-107]. Although the molecular identity of the MPTP is unknown, the peptidyl-prolyl cis-trans isomerase Cyclophilin D (CypD) has been accepted as a major mPTP regulator [108]. Cyclophilin D, localized in the mitochondrial matrix, was found to increase in $A D$-affected brain regions. $A \beta$ binds to $C y p D$, and the $A \beta-$ CypD complex was detected in $A \beta$-rich mitochondria from $A D$ brain and transgenic $\mathrm{AD}$ mice $[44,82]$. These studies found that CypD deficiency prevented $\mathrm{A} \beta$-mediated mitochondrial and synaptic dysfunction, suggesting that the effects of $A \beta$ to induce mPTP opening are mediated through its interaction with $\mathrm{CypD}$ ( $\mathrm{A} \beta$ binding partner). The role of the MPTP in cerebral EC mitochondrial dysfunction has not been fully studied in the context of CAA and AD. However, we will attempt to highlight its possible role in mediating mitochondrial dysfunction and inflammation.

Several studies have demonstrated that cyclosporin A (CsA), an inhibitor of CypD, protects against inflammation. In BMDMs, treatment with CsA inhibited caspase- 1 release and IL-1 $\beta$ secretion after LPS and ATP treatment $[99,109,110]$. However, CypD $D^{-/-}$ macrophages still exhibited NLRP3 activation [109] questioning whether the MPTP opening is involved in NLRP3 activation. It should be pointed out that CsA is not a specific CypD inhibitor, as it also targets calcineurin, a serine/threonine protein phosphatase in the cytosol [111], thereby suggesting that the effects of CsA on inflammasome activation are mPTP-independent. Further studies are required to establish the role of the mPTP in NLRP3 and inflammasome activation by using more specific CypD inhibitors such as sanglifehrin A (SfA) [111]. It is also important to consider that none of these drugs completely inhibit mPTP activation; CypD is an important mPTP regulator but not an 
essential component, as $\mathrm{CypD}^{-/-}$cells are still able to form the mPTP [112]. Therefore, current data does not confirm or exclude the participation of the MPTP in NLRP3 activation. In addition, the use of direct (CypD independent) mPTP inhibitors $[113,114]$ could also shed a light on the role of the mPTP in A $\beta$-mediated mitochondrial dysfunction and NLRP3 inflammasome activation in cerebral ECs during CAA and AD pathology.

One of the key inducers of mPTP formation is an increase in mtROS [115,116]. This phenomenon is commonly known as "ROS induced ROS release" [87], when mPTP-induced ROS in one mitochondrion triggers MPTP opening in adjacent mitochondria with subsequent ROS release. Therefore, the MPTP would be a viable mechanism for A $\beta$-induced $\mathrm{mtROS}$ release in cerebral ECs, which may lead to the activation of inflammation in the neurovascular unit. Interestingly, the formation of the MPTP has been suggested to mediate the release of mtDNA from mitochondria into the cytoplasm $[117,118]$. Cytoplasmic mtDNA has been extensively recognized as a DAMP and mediator of the inflammatory response in other pathologies [26,119]. Overall, the MPTP opening in cerebral ECs may be involved in the A $\beta$-induced release of mitochondrial DAMPs (mtROS, mtDNA), which can result in inflammation.

\subsection{Mitochondrial DNA}

The double stranded mtDNA lacks exons and introns, is circular, packaged into nucleoids instead of histones [120], and contains hypomethylated CpG nucleotides, making mtDNA share more similarities to bacterial DNA than to nuclear DNA. Indeed, one of the first studies by Collins et al. demonstrated that injection of mtDNA, but not nuclear DNA, into mice joints lead to inflammation, increased activity of NFKB, and elevated $\mathrm{TNF} \alpha$ production [121]. Since then, an increasing amount of literature has confirmed the inflammatory nature of mtDNA and identified several pathways involved in mtDNAinduced inflammatory responses [119,122].

Cytoplasmic double stranded DNA (dsDNA) is recognized by cyclic GMP-AMP synthase (cGAS). This enzyme recognizes dsDNA in a sequence-independent manner. Therefore, it can recognize both pathogen and host dsDNA, such as the mtDNA. Once activated by dsDNA, cGAS generates cyclic GMP-AMP (cGAMP) from ATP and GTP, which then activates the stimulator of interferon genes (STING) on the endoplasmic reticulum (ER) membrane [123]. Activated STING induces the phosphorylation and activation of the transcription factors interferon regulatory factor 3 (IRF3) and NFKB $[118,124,125]$, among other mediators of inflammation. Confirming this mechanism, studies have shown that in retinal [118] and lung [126] microvascular ECs, the release of mtDNA to the cytoplasm resulted in the activation of the cGAS-STING pathway and pro-inflammatory transcription factors IRF3 and NFKB. Additionally, exogenous administration of mtDNA to retinal microvascular ECs induced the activation of the cGAS-STING pathway [118]. Thus, many studies confirm that cytosolic mtDNA is capable of inducing an inflammatory response, however, the mechanisms of its release from mitochondria into the cytoplasm have yet to be fully elucidated.

Recent studies have suggested that the release of mtDNA from mitochondria to the cytoplasm can occur through gasdermin D-pore forming complexes in the mitochondrial membrane [126], Bax/Bak-induced OMM permeabilization [127], or mPTP in the IMM $[117,118]$. For example, permeabilization of the IMM induced mtDNA release during apoptosis and, accordingly, deletion of Bax/Bak prevented the mtDNA release and interferon upregulation in murine ECs [127]. Although the mechanism by which mtDNA is released is still under debate, it certainly involves the permeabilization of the OMM and IMM. Importantly, these studies confirm that the release of mtDNA triggers an inflammatory response through the cGAS-STING pathway. Although this pathway has been studied in ECs in various pathological contexts $[118,125,126]$, its role in cerebrovascular inflammation and amyloidosis is still to be defined.

In addition to its role in the activation of the cGAS-STING pathway, mtDNA has been implicated in NLRP3 inflammasome activation. It was found that NLRP3 is required for 
mPTP formation and release of mtDNA into the cytosol in BMDMs [99]. Several studies have indirectly linked ROS and mitochondrial dysfunction to the release of mtDNA and activation of the NLRP3 inflammasome. In human umbilical vein ECs, mtDNA-related NLRP3 inflammasome activation was observed in the presence of ROS [128]. Likewise, oxidized mtDNA bound to and activated NLRP3 in the presence of ATP-induced mitochondrial dysfunction in macrophages [110]. Interestingly, BMDMs lacking the mitochondrial transcription factor TFAM (transcription factor A, mitochondrial), which results in reduced mtDNA content, were resistant to NLRP3 activators as observed by the reduced mtROS production and lack of caspase- 1 and IL-1 $\beta$ activation [85]. Therefore, increasing evidence suggests that mtDNA could induce NLRP3 inflammasome. However, whether this activation is a direct result of $\mathrm{mtDNA}$ release into the cytosol or it is mediated by $\mathrm{mtROS}$ release, a known activator of NLRP3, remains to be clarified.

TLR9 is a nucleotide-sensing receptor that is localized in endolysosome compartments and recognizes unmethylated cytidine-phosphate-guanosine (CpG) oligonucleotides, a characteristic that is common in DNA from bacterial origin and mtDNA. The activation of TLR9 results in the downstream activation of NFKB and the expression of pro-inflammatory cytokines [122]. Interestingly, artificial stimulation of TLR9 was able to reduce vascular plaque burden and improve cognition in Tg2576 and 3xTg animal AD models [129,130]. These data suggest that transient activation of TLR9 may induce a beneficial inflammatory response, however, the threshold for the pathological consequences of mtDNA activation of TLR9 is still unclear. Although TLR9 is expressed in ECs [131,132], to our knowledge the effect of mtDNA on TLR9 in cerebral ECs has not been investigated.

Altogether, a large body of studies demonstrate that different mitochondrial components act as DAMPs and trigger an inflammatory response by activating various pathways such as the NLRP3 inflammasome, the cGAS-STING pathway, and TLR9. The most studied mitochondrial DAMPs are the release of mtROS and mtDNA associated with mPTP opening and other mitochondrial alterations. In addition, cardiolipin, a signature phospholipid of mitochondria that is solely localized in the IMM, has been shown to activate the NLRP3 inflammasome [133]. Overall, mitochondria have been recognized as a central sensor and key mediator of inflammation and cell death that may play a critical role in the pathogenesis of inflammation in cerebral ECs during AD and CAA.

\section{Amyloid Induces Inflammation at the Vascular Endothelium}

Although it is unclear if vascular inflammation and dysfunction occur before or after microglial activation and neurodegeneration, it is likely that vascular inflammation and dysfunction drive and perpetuate neurodegeneration during CAA. One of the earliest pathological findings of human AD brains is the loss of the BBB integrity [33,134-137], which has been confirmed through in vivo and in vitro studies $[28,138,139]$. Early BBB permeability could be a consequence of oligomeric $A \beta$ toxicity on ECs and its effects on mitochondrial function $[27,28,140]$. Mitochondrial DAMPs induced by A $\beta$ or other vascular risk factors may activate inflammatory pathways that lead to vascular inflammation, immune cell recruitment, increased BBB permeability, and NVU dysfunction (Figure 2). This process may then precipitate neuroinflammation and neurodegeneration, important hallmarks of advanced AD.

Cell adhesion molecules expressed and released by activated ECs are involved in the recruitment of immune cells during inflammation [141]. Specifically, in AD patients, the levels of ICAM-1, VCAM-1, and E-selectin are higher in comparison to aged-matched controls [142,143] and, in particular, VCAM-1 closely associates with deficiencies in shortterm memory, spatial function, and white matter changes, suggesting that it may have important biomarker capabilities [144]. Animal models of amyloidosis recapitulate the results of studies obtained in AD patients with increased levels of P-selectin, E-selectin, VCAM-1, and ICAM-1 [24]. The expression of cell adhesion molecules VCAM-1, ICAM-1, E-selectin, and P-selectin in AD may be mediated by $\mathrm{A} \beta$, which was shown to promote their induction in ECs without affecting cell viability [24]. The intracellular mechanism by 
which $A \beta$ accomplishes this may rely on its effect on the mitochondria and the induction of mtROS [145,146].

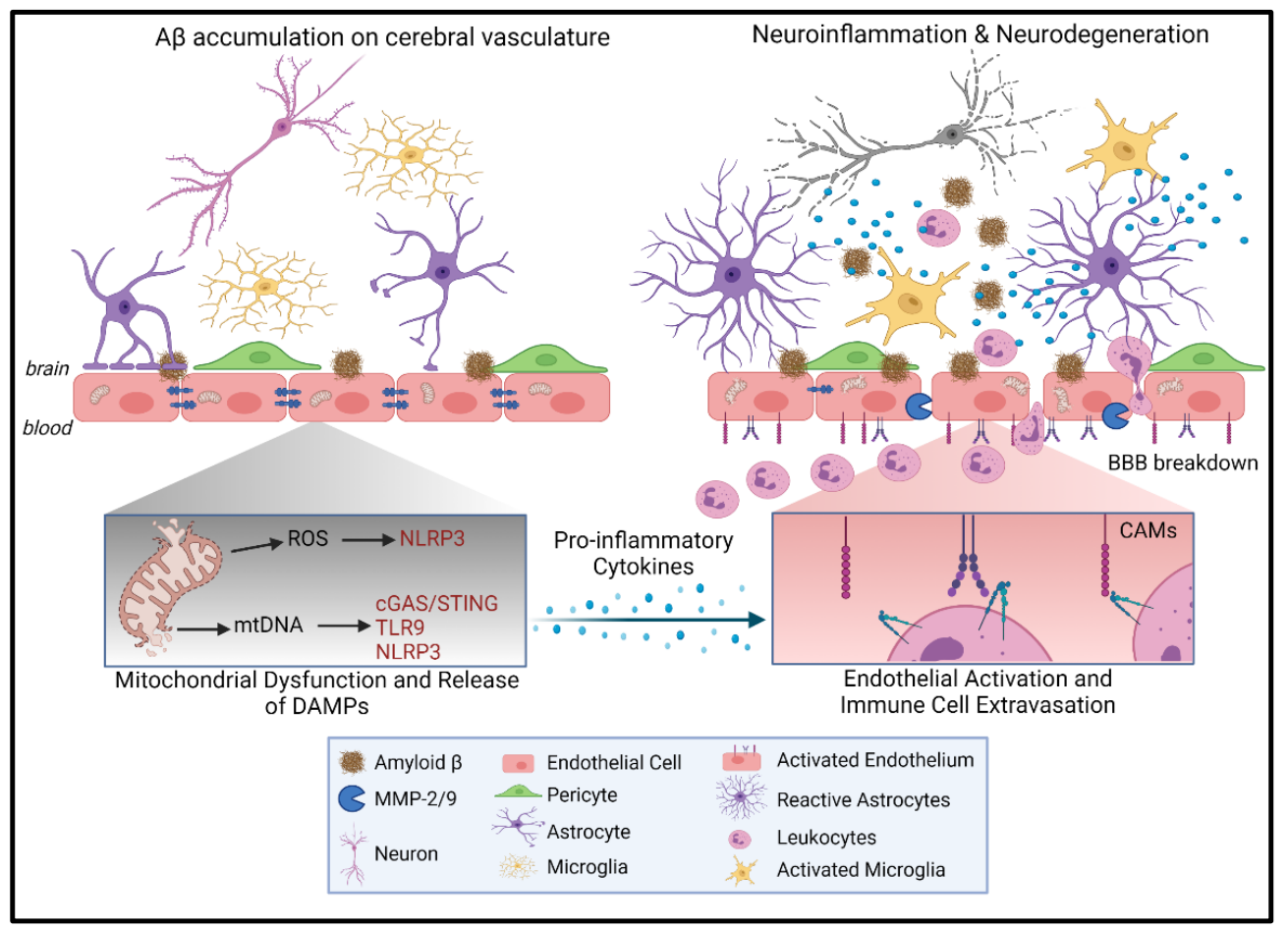

Figure 2. Vascular inflammation and immune cell extravasation drive neuroinflammation and neurodegeneration. The A $\beta$-mediated release of mitochondrial DAMPs, such as mitochondrial reactive oxygen species (mtROS) and mitochondrial DNA (mtDNA), from endothelial cells (EC) induces a perivascular inflammatory response. This in turn, results in EC activation, characterized by the expression of cell adhesion molecules (CAMs). These CAMs, expressed on the EC membrane, induce the recruitment of circulating immune cells through receptor binding. Immune extravasation occurs through the blood-brain barrier (BBB) due to loss of BBB integrity. Loss of BBB integrity is mediated by the matrix metalloproteinases (MMP) MMP2 and MMP9 and the downregulation of tight junction proteins. Infiltrated immune cells also secrete pro-inflammatory cytokines resulting in activation of astrocytes and microglia, which then release additional pro-inflammatory cytokines. This perpetuated immune activation leads to neurovascular cell damage and neurodegeneration. Figure created with BioRender.com.

As discussed in previous sections, a consequence of the A $\beta$-RAGE interaction is the induction of mtROS. In human aortic ECs, activation of RAGE by the AGEs causes the induction of VCAM-1 through NFkB [95]. Therefore, the cellular effects of the A $\beta-$ RAGE binding, such as the upregulation of mtROS [94], may stimulate the expression of CAMs. Other promoters of inflammation include the vascular endothelial growth factors (VEGFs) [147], which are able to stimulate the expression of CAMs through NFkB [148]. Indeed, sunitinib, an inhibitor of tyrosine kinase receptors such as VEGFR, improved memory and learning in animal models of amyloidosis [15]. Overall, these studies highlight the role of VEGF and RAGE in EC activation.

In addition to ROS, mtDNA serves as a mediator of EC inflammatory activation. In primary rat heart ECs, stimulation with dsDNA such as that from dying cells activated NFKB-dependent induction of cell adhesion molecules through the actions of TNF $\alpha$ [149], effects that, as discussed above, may be mediated at least partially through mtDNA [118]. Indeed, TNF $\alpha$ induced the expression of VCAM1, ICAM1, E-selectin, and chemokines in HUVEC cells [150]. In conclusion, A $\beta$ induces EC dysfunction and the release of 
mitochondrial DAMPs such as ROS and mtDNA, which may lead to the activation of inflammatory pathways and the subsequent expression of CAMs.

Importantly, the expression of the CAMs in cerebral ECs of AD brains facilitates the recruitment of inflammatory cells. Expression of VCAM-1 in cerebral ECs leads to lymphocyte infiltration into the brain parenchyma [151]. The recruitment of these immune cells may be mediated, at least in part, by the binding of very late antigen-4 (VLA-4) receptors on lymphocytes to VCAM-1 on ECs [152,153]. In rat brain ECs, ICAM-1 cross-linking has been shown to induce $\mathrm{Ca}^{2+}$ signaling via PKC pathway, which is required for lymphocyte migration through the BBB [154]. Additionally, RAGE was proposed as an EC adhesion receptor and leukocyte recruiter [155]. On the other hand, neutrophils can adhere to the endothelium through the expression of lymphocyte function-associated antigen 1 (LFA-1). $A \beta 42$ induces neutrophil activation, in association with ROS generation [24], and enhances the binding of neutrophils to ECs by inducing the high affinity state conformation of LFA-1, a conformational change that dramatically increases its affinity for ICAM [24,156]. Interestingly, the removal of LFA-1 prevents neutrophil infiltration and cognitive decline, suggesting that vascular damage and inflammation may be one of the earliest steps of $\mathrm{AD}$ progression [24]. The infiltration of neutrophils also triggers the release of IL-17 [24], which increases BBB permeability $[157,158]$. Understanding the effects of A $\beta$ on EC-mediated immune cell migration into the brain parenchyma is important, as the infiltration of immune cells is correlated with the onset of cognitive impairment.

Increased BBB permeability is observed in CAA and AD brains [135,159-162] and is a widely known effect of $A \beta$ on the cerebral vasculature $[28,93,163]$. In mouse brain ECs, $\mathrm{A} \beta 42$ binding to RAGE resulted in the downregulation of the TJ proteins occludin and ZO1 , and increased EC barrier permeability [164]. In addition to the decreased expression of TJ proteins, which has been observed in $\mathrm{AD}[28,165]$, expression of matrix metalloproteinases (MMPs) has also been associated with increased BBB permeability $[137,159,166,167]$. Treatment of brain ECs with $A \beta$ leads to an increase in BBB permeability associated with enhanced expression of MMP2 and MMP9 $[15,93,168]$, results that were also observed in the Tg2576 and 3xTg mouse models of AD [15]. In summary, high BBB permeability as a result of $A \beta$-induced vascular toxicity and inflammation allows the passage of peripheral immune cells and blood components into the brain parenchyma, where they are involved in the activation of microglial cells, the resident immune cells of the brain $[24,169,170]$, and in the stimulation of multiple proinflammatory pathways.

\section{Vascular Inflammation, Mitochondria, and Neuroinflammation}

Microglial activation is mediated, at least in part, through the release of pro-inflammatory cytokines by invading neutrophils, as mentioned above [24]. However, the mitochondria are also important regulators of microglia activation. Extracellular $\mathrm{CytC}$, which is normally released by dying cells, stimulates release of $\mathrm{NO}$, an inflammation mediator, in murine microglial cells $[26,171]$. Additionally, extracellular TFAM in combination with IFN- $\gamma$ augments the secretion of IL-6 in primary human microglial cells [26,172]. In the postmortem human $\mathrm{AD}$ hippocampus, mitochondrial morphology is altered, indicative of accumulated mitochondrial damage [66]. Damaged mitochondria are physiologically eliminated through the process of mitophagy (mitochondrial autophagy). In animal models of $\mathrm{AD}$, mitophagy was decreased in over $50 \%$ of microglia and this was associated with an increase in the number of defective mitochondria [66]. Defects in mitophagy may lead to inflammation due to the release of mitochondrial DAMPs to the extracellular space or into the cytoplasm, resulting in cellular damage $[99,173,174]$. Consequently, induction of mitophagy in $\mathrm{AD}$ microglia increases the efficiency of $\mathrm{A} \beta$ phagocytosis, reducing $\mathrm{A} \beta$ accumulation and prevented cognitive impairment in the APP/PS1 mice [66], probably due to the re-establishment of proper energy supply, as a result of the removal of damaged mitochondria.

The process of mitophagy is coupled to mitochondrial dynamics, as mitochondrial fission appears to be a requirement for mitophagy [175-177]. Mitochondrial fission often 
results in dysfunctional and fragmented mitochondria and the balance between fission and fusion is regulated by fusion proteins, including mitofusin 1 (Mfn1) and 2 (Mfn2), and optic atrophy 1 (OPA-1), and fission proteins, such as dynamin-1-like protein (DRP-1) and mitochondrial fission 1 protein (Fis1). In cynomolgus macaques, the expression of mitochondrial fusion proteins (Mfn1, Mfn2, and OPA-1) was reduced and the fission protein DRP-1 was increased after ventricular infusion of oligomeric $A \beta$, indicating disruption of mitochondrial dynamics and induction of fission [178]. We have recently shown that $\mathrm{Ca}^{2+}$-induced mPTP opening in vitro enhances proteolytic cleavage of L-OPA1 leading to accumulation of S-OPA1 [179], indicating a crosstalk between mPTP opening and mitochondrial dynamics. Based on these data, the mPTP-mediated inflammatory response in cerebral ECs may also be mediated through the inactivation of OPA1, which would increase the number of fragmented mitochondria. Importantly, stimulation of mitophagy, which potentially eliminates damaged mitochondria, was able to reduce NLRP3/caspase-1 mediated neuroinflammation in the APP/PS1 cortex [66]. Since mitophagy stimulation can abrogate the activation of inflammation, $A \beta$-induced mtROS per se, released to the cytoplasm, may act as the primary DAMP and trigger NLRP3 activation. Indeed, protective effects of mitophagy are mediated through the downregulation of mtROS by maintaining a healthy mitochondrial pool. In favor of this hypothesis, IL-10, an anti-inflammatory cytokine, protected against LPS-induced mitochondrial dysfunction, stimulated mitophagy, and prevented NLRP3 inflammasome activation induced by mtROS in BMDM [66,180]. Overall, the positive effects of mitophagy stimulation in APP/PS1 mice portray mitochondrial dysfunction as a causative event towards $\mathrm{AD}$ pathology.

Prolonged activation of microglia is common around $A \beta$ plaques [181], where these cells are involved in the phagocytosis of $A \beta$ and internalization to lysosomal compartments. Internalization of $A \beta$ induces lysosomal swelling and dysfunction, and the release of cathepsin B, a cysteine protease located in the endolysosomal compartment, into the cytoplasm. Cytoplasmic cathepsin B has been proposed as the culprit of NLRP3 activation [181] and was previously detected in plaque-associated microglia [182]. It has also been shown to induce mitochondrial dysfunction through its degradation of TFAM resulting in mtROS production, a key NLRP3 activator $[183,184]$. Cathepsin B has also been implicated in the release of CytC from mitochondria [185] and ferroptosis [186]. Therefore, it is possible that the activation of NLRP3, as well as other inflammatory pathways, may be mediated by a variety of intracellular stress signals including cathepsin B-mediated mitochondrial damage and the subsequent release of mitochondrial DAMPs. Additionally, the defective lysosomes that secrete cathepsin $B$ due to $A \beta$ internalization may also result in the accumulation of damaged mitochondria due to inhibition of mitophagy. Interestingly, in microglia that lacked the NLRP3 inflammasome, the M2 phenotype predominated, leading to a decrease in A $\beta$ deposition and improvement in spatial memory in APP/PS1 mice [65]. Additionally, the release of ASC specks from microglia has been shown to increase amyloid aggregation [187] suggesting that the NLRP3 is not only involved in the activation of inflammation, but also plays a role in $A \beta$ deposition.

Activation of microglia also has detrimental effects on the brain vasculature perpetuating the already present damage. IL- $1 \beta$ released from activated microglia increased BBB permeability, downregulated the expression of TJ proteins (ZO-1, occludin, and claudin-5), and suppressed sonic hedgehog production from astrocytes, thereby reducing their protection towards BBB integrity [188]. Furthermore, the release of IL-1 $\beta$ from microglia also increased astrocytic activation leading to the production of pro-inflammatory cytokines $\mathrm{C}-\mathrm{C}$ Motif Chemokine Ligand 2 (CCL2), CCL20, and C-X-C motif chemokine ligand 2 (CXCL2) that induce cell migration and exacerbate BBB disruption and neuroinflammation [188]. Interestingly, LPS-activated microglia increased EC barrier permeability and reduced the expression of ZO-1, occludin, and claudin-5 [189]. In conclusion, these studies demonstrate that the EC activation and BBB damage that lead to the activation of microglia are perpetuated by the further release of pro-inflammatory mediators from the microglia towards the brain vasculature. 
Systemic inflammation leads to microglial recruitment to blood vessels through the chemokine receptor type 5 (CCR5), led by the release of the chemokine CCL5 by brain ECs. Microglia then start expressing claudin-5, which helps in the retention of BBB tightness [190]. Hence, the movement of glial cells $[190,191]$ towards an activated vasculature and their upregulation of claudin and occludin proteins appears to be an initial protective mechanism to prevent worsening of vascular function. Indeed, transient activation of TLR9 was shown to decrease parenchymal and vascular $A \beta$ pathology and improve cognitive function in various AD mouse models and in squirrel monkeys [130,192,193], suggesting that the initial activation of inflammation may be beneficial. However, a sustained inflammatory state may lead to a CD68 phagocytic phenotype and disruption of the BBB [190]. Similarly, sustained elevated levels of IL-17 induce EC dysfunction in mice fed with high salt diet, characterized by inhibition of eNOS and cognitive dysfunction [157]. Expression of RAGE in microglia of transgenic mice expressing a mutant human APP, induced IL-1 $\beta$ and TNF $\alpha$ production [92]. TNF $\alpha$, in turn, has been shown to reduce the expression of claudin-5 in a NFKB-dependent manner in brain ECs [194]. Another study demonstrated that the expression of RAGE in microglia in AD subjects was higher compared to nondemented individuals [195]. A recent study using an endothelial and astrocyte co-culture demonstrated that $A \beta 42$ counteracts the increase of CAMs in the presence of inflammatory mediators, inhibiting PBMC migration. However, the observed effects of $A \beta$ were only present in the co-culture model, suggesting that astrocytes protect the BBB from immune cell extravasation [196]. In conclusion, vascular inflammation is an early event in CAA and $\mathrm{AD}$ and appears to influence neuroinflammation and progression of neurodegeneration. The mitochondria are portrayed as a central regulator of vascular activation and neuroinflammation. As a result, therapeutic strategies that prevent mitochondrial dysfunction may be also effective to reduce neuroinflammation and neurodegeneration.

\section{Therapeutic Strategies}

An increasing number of studies have centered on the mitochondrion as an initiator, sensor, and even messenger of danger signals. In this review, we portray the EC mitochondria as important initiators of $A \beta$-induced vascular inflammation. Therefore, therapies that prevent mitochondrial dysfunction and/or neutralize the release of mitochondrial DAMPs might prevent the activation of vascular inflammation and neurodegeneration. The most well-known mitochondrial DAMPs are mtROS, therefore therapies that prevent $\mathrm{mtROS}$ generation or neutralize it (such as antioxidants) could be explored as an attractive target to prevent the activation of endothelial cells in the context of CAA and AD.

Multiple mitochondria-targeted antioxidant peptides have been developed, one of which is mitoquinone (MitoQ). MitoQ is a cationic ubiquinone derivative antioxidant targeted to the mitochondria in a membrane-potential-dependent manner [197]. In microglia, MitoQ was shown to prevented mtROS and NLRP3 activation in a model of intracerebral hemorrhage [198]. Similarly, in pulmonary aortic EC, MitoQ reduced TNF $\alpha$ induced expression of ICAM-1 and NFKB [199]. However, further studies demonstrated that higher concentrations of MitoQ could induce ICAM-1 expression through the induction of ROS production [199,200], carbonylation, and glutathionylation of cellular proteins [199]. Therefore, the potential benefits of MitoQ as powerful mitochondria-targeted antioxidant are controversial.

In addition to MitoQ, another peptide was developed called the Szeto-Schiller-31 (SS-31) peptide. The peptide SS-31 is a mitochondria-targeted antioxidant that mostly accumulates in the IMM, the major site for mtROS production, and can cross the BBB [201,202]. Treatment of aged WT mice with SS-31 improved CBF, neurovascular coupling, and spatial learning [203]. In addition, in primary cerebrovascular ECs from aged rats, SS-31 improved mitochondrial respiration and reduced mtROS production [203], suggesting that SS-31 could potentially inhibit the mtROS-induced inflammatory response. Indeed, SS-31 was able to reduce LPS-induced oxidative stress and inflammation in murine microglia [204], and in the mouse hippocampus it prevented mitochondrial dysfunction, oxidative stress, 
inflammation, memory impairments, and neuronal death in the presence of LPS [205]. Although SS-31 has been studied in the context of AD with positive results (reviewed in [202]), the potential role of SS-31 in preventing cerebrovascular EC activation in models of CAA or AD is still unclear.

In addition to mtROS, inhibition of the $\mathrm{mPTP}$, which can be activated by $\mathrm{mtROS}[115,116]$, would be an attractive strategy to prevent $A \beta$-induced mitochondrial dysfunction and inflammation. The formation of the MPTP has been linked to mtROS and the release of mtDNA into the cytoplasm $[117,118]$. As a result, mPTP inhibition would prevent the release of mitochondrial DAMPs and the activation of the downstream inflammatory pathways. Several studies have demonstrated that drugs that inhibit CypD, such as SfA and CsA, are able to prevent the activation of inflammation. CsA was demonstrated to prevent LPS-induced caspase- 1 activation and IL-1 $\beta$ secretion in BMDM $[99,109,110]$ and was able to prevent astrocytic reactivity in AD models [206], albeit through calcineurin inhibition [111]. Interestingly, in human aortic ECs SfA inhibited mtROS production and improved vascular relaxation in a model of hypertension [207]. However, it was reported that $\mathrm{CypD}^{-/-}$macrophages still exhibited NLRP3 activation [109], raising the question of whether these drugs are sufficient to inhibit MPTP formation or if the MPTP is at all involved in the release of mitochondrial DAMPs into the cytoplasm. As a result, further studies are required to assess the potential of CsA and SfA as inhibitors of inflammation. One of the most challenging aspects of MPTP inhibition is the lack of knowledge on the molecular identity of the $\mathrm{MPTP}$, making the development of specific pharmacological inhibitors impossible. Taking into consideration that the mPTP is involved in other diseases with an inflammatory component [101-107], studies aiming at elucidating the molecular identity of the MPTP and the development of specific MPTP inhibitors would be of great interest to the scientific community.

Finally, recent evidence has demonstrated that carbonic anhydrase inhibitors (CAi), a family of FDA-approved, BBB-permeable drugs, may have protective roles on the mitochondria. Cytochrome $c$ is normally located in the outer part of the IMM, and its release into the cytosol is indicative of mitochondrial damage and OMM rupture. The CAi Methazolamide (MTZ) was found to inhibit CytC release out of a list of compounds from the NINDS library of neurodegeneration drug screening consortium [208]. It was shown that MTZ prevents $\mathrm{A} \beta$-induced $\mathrm{mtROS}$ production, $\mathrm{CytC}$ release, and caspase activation in neuronal and glial cells in culture and prevented neurodegeneration in mice after intra-hippocampal A $\beta$ injection [209]. Furthermore, both MTZ and Acetazolamide (ATZ), another clinically used $C A i$, tested in cells of the neurovascular unit challenged with $A \beta$, prevented loss of mitochondrial membrane potential and mtROS production [27]. For an in-depth review on the therapeutic potential of $\mathrm{CA}$ in the context of $\mathrm{CAA}$ and $\mathrm{AD}$, the reader is directed elsewhere [210]. Although the role of MTZ and ATZ in EC activation during CAA and $\mathrm{AD}$ has not been fully investigated, it is conceivable that the protective effect they have on mitochondrial function might translate into decreased $E C$ activation in the presence of $A \beta$.

In conclusion, drugs that prevent mitochondrial dysfunction or provide antioxidant capabilities could provide protection against EC activation, and possibly EC death. However, it is important to also consider other risk factors that have been associated with AD, such as APOE status. The presence of the APOE4 allele dramatically increases the risk for developing AD with age, decreases the age of onset [211,212], and is considered the major genetic risk factor for late-onset $\mathrm{AD}$. Individuals with $\mathrm{APOE} 4(\varepsilon 3 / \varepsilon 4$ and $\varepsilon 4 / \varepsilon 4$ alleles) develop increased BBB permeability in the hippocampus and medial temporal lobe, and cognitive decline independent of their $A \beta$ and Tau pathology [213]. Furthermore, APOE4 has also been linked to mitochondrial dysfunction [214-216]. Therefore, it is critical to evaluate how risk factors, such as APOE status, might add a level of complexity to mitochondria-targeted therapies. 


\section{Conclusions}

Overall, current knowledge suggests that amyloid and vascular risk factors can cause mitochondrial dysfunction and ROS production in cerebral ECs, thereby stimulating vascular inflammation. This vascular activation induces immune cell recruitment, with microglial and astrocytic activation. The resulting widespread inflammatory cascade, in turn, has been shown to precipitate endothelial and neurovascular mitochondrial damage, eliciting a detrimental impact on the BBB. As a result, a progressive worsening of vascular function and neuroinflammation, loss of BBB integrity, and impaired $\mathrm{A} \beta$ clearance will further perpetuate neurodegeneration, accelerating the development and progression of dementia and AD. Understanding the mechanisms involved in the pathogenesis of neural and vascular inflammation during AD and CAA will allow the development of new therapeutic strategies for the treatment of patients with AD and other neurodegenerative diseases. A growing number of studies suggest a potential role of the mitochondria as a nexus of stress in mediating inflammatory signaling in cerebral ECs and other neurovascular cells, underlining the importance of further studies in this area.

Author Contributions: Conceptualization, R.M.P.-R. and S.F.; Resources, R.M.P.-R., S.J. and S.F.; Writing-Original Draft Preparation, R.M.P.-R.; Writing-Review \& Editing, S.J. and S.F.; Visualization, R.M.P.-R., S.J. and S.F.; Supervision, S.F.; Project Administration, S.F.; Funding Acquisition, R.M.P.-R. and S.F. All authors have read and agreed to the published version of the manuscript.

Funding: This research was funded by The Brody Family Medical Trust Fellowship in Incurable Diseases of The Philadelphia Foundation (to RPR); NIH R01NS104127 and R01AG062572, the Edward N. and Della L. Thome Memorial Foundation Award in Alzheimer's Disease Drug Discovery Research, the Pennsylvania Department of Heath Collaborative Research on Alzheimer's Disease (PA Cure) Grant, the Karen Toffler Charitable Trust, and the Lemole Center for Integrated Lymphatics research (to SF).

Institutional Review Board Statement: Not applicable.

Informed Consent Statement: Not applicable.

Conflicts of Interest: The authors declare no conflict of interest.

\section{References}

1. Alzheimer's Association. 2021 Alzheimer's disease facts and figures. Alzheimers Dement. 2021, 17, 327-406. [CrossRef]

2. Sevigny, J.; Chiao, P.; Bussiere, T.; Weinreb, P.H.; Williams, L.; Maier, M.; Dunstan, R.; Salloway, S.; Chen, T.; Ling, Y.; et al. The antibody aducanumab reduces Abeta plaques in Alzheimer's disease. Nature 2016, 537, 50-56. [CrossRef]

3. Knopman, D.S.; Jones, D.T.; Greicius, M.D. Failure to demonstrate efficacy of aducanumab: An analysis of the EMERGE and ENGAGE trials as reported by Biogen, December 2019. Alzheimers Dement. 2021, 17, 696-701. [CrossRef] [PubMed]

4. Koike, H.; Iguchi, Y.; Sahashi, K.; Katsuno, M. Significance of Oligomeric and Fibrillar Species in Amyloidosis: Insights into Pathophysiology and Treatment. Molecules 2021, 26, 5091. [CrossRef]

5. Avila, J.; Perry, G. A Multilevel View of the Development of Alzheimer's Disease. Neuroscience 2021, 457, 283-293. [CrossRef]

6. Sweeney, M.D.; Montagne, A.; Sagare, A.P.; Nation, D.A.; Schneider, L.S.; Chui, H.C.; Harrington, M.G.; Pa, J.; Law, M.; Wang, D.J.J.; et al. Vascular dysfunction-The disregarded partner of Alzheimer's disease. Alzheimers Dement. 2019, 15, 158-167. [CrossRef]

7. Arvanitakis, Z.; Capuano, A.W.; Leurgans, S.E.; Bennett, D.A.; Schneider, J.A. Relation of cerebral vessel disease to Alzheimer's disease dementia and cognitive function in elderly people: A cross-sectional study. Lancet Neurol. 2016, 15, 934-943. [CrossRef]

8. Alakbarzade, V.; French, J.M.; Howlett, D.R.; Attems, J.; Francis, P.T.; Stratton, S.; Clark, C.N.; Pereira, A.C.; Hainsworth, A.H. Cerebral amyloid angiopathy distribution in older people: A cautionary note. Alzheimers Dement. 2021, 7, e12145. [CrossRef]

9. DeSimone, C.V.; Graff-Radford, J.; El-Harasis, M.A.; Rabinstein, A.A.; Asirvatham, S.J.; Holmes, D.R., Jr. Cerebral Amyloid Angiopathy: Diagnosis, Clinical Implications, and Management Strategies in Atrial Fibrillation. J. Am. Coll. Cardiol. 2017, 70, 1173-1182. [CrossRef] [PubMed]

10. Koike, H.; Ikeda, S.; Takahashi, M.; Kawagashira, Y.; Iijima, M.; Misumi, Y.; Ando, Y.; Ikeda, S.I.; Katsuno, M.; Sobue, G. Schwann cell and endothelial cell damage in transthyretin familial amyloid polyneuropathy. Neurology 2016, 87, 2220-2229. [CrossRef] [PubMed]

11. Nakamura, M.; Yamashita, T.; Ueda, M.; Obayashi, K.; Sato, T.; Ikeda, T.; Washimi, Y.; Hirai, T.; Kuwahara, Y.; Yamamoto, M.T.; et al. Neuroradiologic and clinicopathologic features of oculoleptomeningeal type amyloidosis. Neurology 2005, 65, 1051-1056. [CrossRef] [PubMed] 
12. Sekijima, Y.; Yazaki, M.; Oguchi, K.; Ezawa, N.; Yoshinaga, T.; Yamada, M.; Yahikozawa, H.; Watanabe, M.; Kametani, F.; Ikeda, S. Cerebral amyloid angiopathy in posttransplant patients with hereditary ATTR amyloidosis. Neurology 2016, 87, 773-781. [CrossRef] [PubMed]

13. Tripathy, D.; Sanchez, A.; Yin, X.; Luo, J.; Martinez, J.; Grammas, P. Thrombin, a mediator of cerebrovascular inflammation in AD and hypoxia. Front. Aging Neurosci. 2013, 5, 19. [CrossRef] [PubMed]

14. Blum-Degen, D.; Muller, T.; Kuhn, W.; Gerlach, M.; Przuntek, H.; Riederer, P. Interleukin-1 beta and interleukin-6 are elevated in the cerebrospinal fluid of Alzheimer's and de novo Parkinson's disease patients. Neurosci. Lett. 1995, 202, 17-20. [CrossRef]

15. Grammas, P.; Martinez, J.; Sanchez, A.; Yin, X.; Riley, J.; Gay, D.; Desobry, K.; Tripathy, D.; Luo, J.; Evola, M.; et al. A new paradigm for the treatment of Alzheimer's disease: Targeting vascular activation. J. Alzheimers Dis. 2014, 40, 619-630. [CrossRef]

16. Grammas, P.; Ovase, R. Cerebrovascular transforming growth factor-beta contributes to inflammation in the Alzheimer's disease brain. Am. J. Pathol. 2002, 160, 1583-1587. [CrossRef]

17. Yu, D.; Corbett, B.; Yan, Y.; Zhang, G.X.; Reinhart, P.; Cho, S.J.; Chin, J. Early cerebrovascular inflammation in a transgenic mouse model of Alzheimer's disease. Neurobiol. Aging 2012, 33, 2942-2947. [CrossRef]

18. Quintana, D.D.; Anantula, Y.; Garcia, J.A.; Engler-Chiurazzi, E.B.; Sarkar, S.N.; Corbin, D.R.; Brown, C.M.; Simpkins, J.W. Microvascular degeneration occurs before plaque onset and progresses with age in 3xTg AD mice. Neurobiol. Aging 2021, 105, 115-128. [CrossRef]

19. Park, L.; Koizumi, K.; El Jamal, S.; Zhou, P.; Previti, M.L.; Van Nostrand, W.E.; Carlson, G.; Iadecola, C. Age-dependent neurovascular dysfunction and damage in a mouse model of cerebral amyloid angiopathy. Stroke 2014, 45, 1815-1821. [CrossRef]

20. Bell, R.D.; Zlokovic, B.V. Neurovascular mechanisms and blood-brain barrier disorder in Alzheimer's disease. Acta Neuropathol. 2009, 118, 103-113. [CrossRef]

21. de la Torre, J.C. Is Alzheimer's disease a neurodegenerative or a vascular disorder? Data, dogma, and dialectics. Lancet Neurol. 2004, 3, 184-190. [CrossRef]

22. Morgan, D.; Gordon, M.N.; Tan, J.; Wilcock, D.; Rojiani, A.M. Dynamic complexity of the microglial activation response in transgenic models of amyloid deposition: Implications for Alzheimer therapeutics. J. Neuropathol. Exp. Neurol. 2005, 64, 743-753. [CrossRef]

23. Tesseur, I.; Zou, K.; Esposito, L.; Bard, F.; Berber, E.; Can, J.V.; Lin, A.H.; Crews, L.; Tremblay, P.; Mathews, P.; et al. Deficiency in neuronal TGF-beta signaling promotes neurodegeneration and Alzheimer's pathology. J. Clin. Investig. 2006, 116, 3060-3069. [CrossRef] [PubMed]

24. Zenaro, E.; Pietronigro, E.; Della Bianca, V.; Piacentino, G.; Marongiu, L.; Budui, S.; Turano, E.; Rossi, B.; Angiari, S.; Dusi, S.; et al. Neutrophils promote Alzheimer's disease-like pathology and cognitive decline via LFA-1 integrin. Nat. Med. 2015, 21, 880-886. [CrossRef]

25. Bader, V.; Winklhofer, K.F. Mitochondria at the interface between neurodegeneration and neuroinflammation. Semin. Cell Dev. Biol. 2020, 99, 163-171. [CrossRef]

26. Bajwa, E.; Pointer, C.B.; Klegeris, A. The Role of Mitochondrial Damage-Associated Molecular Patterns in Chronic Neuroinflammation. Mediat. Inflamm. 2019, 2019, 4050796. [CrossRef] [PubMed]

27. Solesio, M.E.; Peixoto, P.M.; Debure, L.; Madamba, S.M.; de Leon, M.J.; Wisniewski, T.; Pavlov, E.V.; Fossati, S. Carbonic anhydrase inhibition selectively prevents amyloid beta neurovascular mitochondrial toxicity. Aging Cell 2018, 17, e12787. [CrossRef]

28. Parodi-Rullan, R.; Ghiso, J.; Cabrera, E.; Rostagno, A.; Fossati, S. Alzheimer's amyloid beta heterogeneous species differentially affect brain endothelial cell viability, blood-brain barrier integrity, and angiogenesis. Aging Cell 2020, 19, e13258. [CrossRef] [PubMed]

29. Grimm, A.; Friedland, K.; Eckert, A. Mitochondrial dysfunction: The missing link between aging and sporadic Alzheimer's disease. Biogerontology 2016, 17, 281-296. [CrossRef]

30. Solis, E., Jr.; Hascup, K.N.; Hascup, E.R. Alzheimer's Disease: The Link Between Amyloid-beta and Neurovascular Dysfunction. J. Alzheimers Dis. 2020, 76, 1179-1198. [CrossRef]

31. Joo, I.L.; Lai, A.Y.; Bazzigaluppi, P.; Koletar, M.M.; Dorr, A.; Brown, M.E.; Thomason, L.A.; Sled, J.G.; McLaurin, J.; Stefanovic, B. Early neurovascular dysfunction in a transgenic rat model of Alzheimer's disease. Sci. Rep. 2017, 7, 46427. [CrossRef]

32. Kelly, P.; Denver, P.; Satchell, S.C.; Ackermann, M.; Konerding, M.A.; Mitchell, C.A. Microvascular ultrastructural changes precede cognitive impairment in the murine APPswe/PS1dE9 model of Alzheimer's disease. Angiogenesis 2017, 20, 567-580. [CrossRef] [PubMed]

33. van de Haar, H.J.; Burgmans, S.; Jansen, J.F.; van Osch, M.J.; van Buchem, M.A.; Muller, M.; Hofman, P.A.; Verhey, F.R.; Backes, W.H. Blood-Brain Barrier Leakage in Patients with Early Alzheimer Disease. Radiology 2016, 281, 527-535. [CrossRef] [PubMed]

34. van de Haar, H.J.; Jansen, J.F.A.; van Osch, M.J.P.; van Buchem, M.A.; Muller, M.; Wong, S.M.; Hofman, P.A.M.; Burgmans, S.; Verhey, F.R.J.; Backes, W.H. Neurovascular unit impairment in early Alzheimer's disease measured with magnetic resonance imaging. Neurobiol. Aging 2016, 45, 190-196. [CrossRef] [PubMed]

35. Hawkins, B.T.; Davis, T.P. The blood-brain barrier/neurovascular unit in health and disease. Pharmacol. Rev. 2005, 57, 173-185. [CrossRef]

36. Abbott, N.J.; Patabendige, A.A.; Dolman, D.E.; Yusof, S.R.; Begley, D.J. Structure and function of the blood-brain barrier. Neurobiol. Dis. 2010, 37, 13-25. [CrossRef] 
37. Oldendorf, W.H.; Cornford, M.E.; Brown, W.J. The large apparent work capability of the blood-brain barrier: A study of the mitochondrial content of capillary endothelial cells in brain and other tissues of the rat. Ann. Neurol. 1977, 1, 409-417. [CrossRef] [PubMed]

38. Claudio, L. Ultrastructural features of the blood-brain barrier in biopsy tissue from Alzheimer's disease patients. Acta Neuropathol. 1996, 91, 6-14. [CrossRef]

39. Parodi-Rullan, R.; Sone, J.Y.; Fossati, S. Endothelial Mitochondrial Dysfunction in Cerebral Amyloid Angiopathy and Alzheimer's Disease. J. Alzheimers Dis. 2019, 72, 1019-1039. [CrossRef]

40. Forrester, S.J.; Preston, K.J.; Cooper, H.A.; Boyer, M.J.; Escoto, K.M.; Poltronetti, A.J.; Elliott, K.J.; Kuroda, R.; Miyao, M.; Sesaki, H.; et al. Mitochondrial Fission Mediates Endothelial Inflammation. Hypertension 2020, 76, 267-276. [CrossRef] [PubMed]

41. Zinovkin, R.A.; Romaschenko, V.P.; Galkin, I.I.; Zakharova, V.V.; Pletjushkina, O.Y.; Chernyak, B.V.; Popova, E.N. Role of mitochondrial reactive oxygen species in age-related inflammatory activation of endothelium. Aging 2014, 6, 661-674. [CrossRef]

42. Jadiya, P.; Kolmetzky, D.W.; Tomar, D.; Di Meco, A.; Lombardi, A.A.; Lambert, J.P.; Luongo, T.S.; Ludtmann, M.H.; Pratico, D.; Elrod, J.W. Impaired mitochondrial calcium efflux contributes to disease progression in models of Alzheimer's disease. Nat. Commun. 2019, 10, 3885. [CrossRef]

43. Esposito, L.; Raber, J.; Kekonius, L.; Yan, F.; Yu, G.Q.; Bien-Ly, N.; Puolivali, J.; Scearce-Levie, K.; Masliah, E.; Mucke, L. Reduction in mitochondrial superoxide dismutase modulates Alzheimer's disease-like pathology and accelerates the onset of behavioral changes in human amyloid precursor protein transgenic mice. J. Neurosci. 2006, 26, 5167-5179. [CrossRef] [PubMed]

44. Du, H.; Guo, L.; Zhang, W.; Rydzewska, M.; Yan, S. Cyclophilin D deficiency improves mitochondrial function and learning/memory in aging Alzheimer disease mouse model. Neurobiol. Aging 2011, 32, 398-406. [CrossRef] [PubMed]

45. Cabrera, E.; Mathews, P.; Mezhericher, E.; Beach, T.G.; Deng, J.; Neubert, T.A.; Rostagno, A.; Ghiso, J. Abeta truncated species: Implications for brain clearance mechanisms and amyloid plaque deposition. Biochim. Biophys. Acta Mol. Basis Dis. 2018, 1864, 208-225. [CrossRef]

46. Carare, R.O.; Aldea, R.; Agarwal, N.; Bacskai, B.J.; Bechman, I.; Boche, D.; Bu, G.; Bulters, D.; Clemens, A.; Counts, S.E.; et al. Clearance of interstitial fluid (ISF) and CSF (CLIC) group-part of Vascular Professional Interest Area (PIA): Cerebrovascular disease and the failure of elimination of Amyloid-beta from the brain and retina with age and Alzheimer's disease-Opportunities for Therapy. Alzheimers Dement. (Amsterdam) 2020, 12, e12053. [CrossRef]

47. Kim, S.H.; Ahn, J.H.; Yang, H.; Lee, P.; Koh, G.Y.; Jeong, Y. Cerebral amyloid angiopathy aggravates perivascular clearance impairment in an Alzheimer's disease mouse model. Acta Neuropathol. Commun. 2020, 8, 181. [CrossRef]

48. Albargothy, N.J.; Johnston, D.A.; MacGregor-Sharp, M.; Weller, R.O.; Verma, A.; Hawkes, C.A.; Carare, R.O. Convective influx/glymphatic system: Tracers injected into the CSF enter and leave the brain along separate periarterial basement membrane pathways. Acta Neuropathol. 2018, 136, 139-152. [CrossRef]

49. Rasmussen, M.K.; Mestre, H.; Nedergaard, M. The glymphatic pathway in neurological disorders. Lancet Neurol. 2018, 17, 1016-1024. [CrossRef]

50. Nedergaard, M.; Goldman, S.A. Glymphatic failure as a final common pathway to dementia. Science 2020, 370, 50-56. [CrossRef]

51. Reeves, B.C.; Karimy, J.K.; Kundishora, A.J.; Mestre, H.; Cerci, H.M.; Matouk, C.; Alper, S.L.; Lundgaard, I.; Nedergaard, M.; Kahle, K.T. Glymphatic System Impairment in Alzheimer's Disease and Idiopathic Normal Pressure Hydrocephalus. Trends Mol. Med. 2020, 26, 285-295. [CrossRef]

52. van Veluw, S.J.; Hou, S.S.; Calvo-Rodriguez, M.; Arbel-Ornath, M.; Snyder, A.C.; Frosch, M.P.; Greenberg, S.M.; Bacskai, B.J. Vasomotion as a Driving Force for Paravascular Clearance in the Awake Mouse Brain. Neuron 2020, 105, 549-561.e545. [CrossRef]

53. Aldea, R.; Weller, R.O.; Wilcock, D.M.; Carare, R.O.; Richardson, G. Cerebrovascular Smooth Muscle Cells as the Drivers of Intramural Periarterial Drainage of the Brain. Front. Aging Neurosci. 2019, 11, 1. [CrossRef]

54. Iliff, J.J.; Wang, M.; Liao, Y.; Plogg, B.A.; Peng, W.; Gundersen, G.A.; Benveniste, H.; Vates, G.E.; Deane, R.; Goldman, S.A.; et al. A paravascular pathway facilitates CSF flow through the brain parenchyma and the clearance of interstitial solutes, including amyloid beta. Sci. Transl. Med. 2012, 4, 147ra111. [CrossRef] [PubMed]

55. Da Mesquita, S.; Louveau, A.; Vaccari, A.; Smirnov, I.; Cornelison, R.C.; Kingsmore, K.M.; Contarino, C.; Onengut-Gumuscu, S.; Farber, E.; Raper, D.; et al. Functional aspects of meningeal lymphatics in ageing and Alzheimer's disease. Nature 2018, 560, 185-191. [CrossRef]

56. Da Mesquita, S.; Papadopoulos, Z.; Dykstra, T.; Brase, L.; Farias, F.G.; Wall, M.; Jiang, H.; Kodira, C.D.; de Lima, K.A.; Herz, J.; et al. Meningeal lymphatics affect microglia responses and anti-Abeta immunotherapy. Nature 2021, 593, 255-260. [CrossRef] [PubMed]

57. de Leon, M.J.; Li, Y.; Okamura, N.; Tsui, W.H.; Saint-Louis, L.A.; Glodzik, L.; Osorio, R.S.; Fortea, J.; Butler, T.; Pirraglia, E.; et al. Cerebrospinal Fluid Clearance in Alzheimer Disease Measured with Dynamic PET. J. Nucl. Med. 2017, 58, 1471-1476. [CrossRef]

58. Mendel, T.A.; Wierzba-Bobrowicz, T.; Lewandowska, E.; Stepien, T.; Szpak, G.M. The development of cerebral amyloid angiopathy in cerebral vessels. A review with illustrations based upon own investigated post mortem cases. Pol. J. Pathol. 2013, 64, 260-267. [CrossRef]

59. Wisniewski, H.M.; Wegiel, J.; Wang, K.C.; Lach, B. Ultrastructural studies of the cells forming amyloid in the cortical vessel wall in Alzheimer's disease. Acta Neuropathol. 1992, 84, 117-127. [CrossRef] [PubMed]

60. Gong, T.; Liu, L.; Jiang, W.; Zhou, R. DAMP-sensing receptors in sterile inflammation and inflammatory diseases. Nat. Rev. Immunol. 2020, 20, 95-112. [CrossRef] 
61. Shibata, M.; Yamada, S.; Kumar, S.R.; Calero, M.; Bading, J.; Frangione, B.; Holtzman, D.M.; Miller, C.A.; Strickland, D.K.; Ghiso, J.; et al. Clearance of Alzheimer's amyloid-ss(1-40) peptide from brain by LDL receptor-related protein-1 at the blood-brain barrier. J. Clin. Investig. 2000, 106, 1489-1499. [CrossRef] [PubMed]

62. Deane, R.; Du Yan, S.; Submamaryan, R.K.; LaRue, B.; Jovanovic, S.; Hogg, E.; Welch, D.; Manness, L.; Lin, C.; Yu, J.; et al. RAGE mediates amyloid-beta peptide transport across the blood-brain barrier and accumulation in brain. Nat. Med. 2003, 9, 907-913. [CrossRef] [PubMed]

63. Cai, Z.; Liu, N.; Wang, C.; Qin, B.; Zhou, Y.; Xiao, M.; Chang, L.; Yan, L.J.; Zhao, B. Role of RAGE in Alzheimer's Disease. Cell Mol. Neurobiol. 2016, 36, 483-495. [CrossRef] [PubMed]

64. Qosa, H.; LeVine, H., 3rd; Keller, J.N.; Kaddoumi, A. Mixed oligomers and monomeric amyloid-beta disrupts endothelial cells integrity and reduces monomeric amyloid-beta transport across hCMEC/D3 cell line as an in vitro blood-brain barrier model. Biochim. Biophys. Acta 2014, 1842, 1806-1815. [CrossRef] [PubMed]

65. Heneka, M.T.; Kummer, M.P.; Stutz, A.; Delekate, A.; Schwartz, S.; Vieira-Saecker, A.; Griep, A.; Axt, D.; Remus, A.; Tzeng, T.C.; et al. NLRP3 is activated in Alzheimer's disease and contributes to pathology in APP/PS1 mice. Nature 2013, 493, 674-678. [CrossRef]

66. Fang, E.F.; Hou, Y.; Palikaras, K.; Adriaanse, B.A.; Kerr, J.S.; Yang, B.; Lautrup, S.; Hasan-Olive, M.M.; Caponio, D.; Dan, X.; et al. Mitophagy inhibits amyloid-beta and tau pathology and reverses cognitive deficits in models of Alzheimer's disease. Nat. Neurosci. 2019, 22, 401-412. [CrossRef] [PubMed]

67. Dobri, A.M.; Dudau, M.; Enciu, A.M.; Hinescu, M.E. CD36 in Alzheimer's Disease: An Overview of Molecular Mechanisms and Therapeutic Targeting. Neuroscience 2021, 453, 301-311. [CrossRef]

68. Garcia-Bonilla, L.; Sciortino, R.; Shahanoor, Z.; Racchumi, G.; Janakiraman, M.; Montaner, J.; Zhou, P.; Anrather, J.; Iadecola, C. Role of microglial and endothelial CD36 in post-ischemic inflammasome activation and interleukin-1beta-induced endothelial activation. Brain Behav. Immun. 2021, 95, 489-501. [CrossRef]

69. Bai, B.; Yang, Y.; Wang, Q.; Li, M.; Tian, C.; Liu, Y.; Aung, L.H.H.; Li, P.F.; Yu, T.; Chu, X.M. NLRP3 inflammasome in endothelial dysfunction. Cell Death Dis. 2020, 11, 776. [CrossRef]

70. Kelley, N.; Jeltema, D.; Duan, Y.; He, Y. The NLRP3 Inflammasome: An Overview of Mechanisms of Activation and Regulation. Int. J. Mol. Sci. 2019, 20, 3328. [CrossRef]

71. Kinoshita, T.; Imamura, R.; Kushiyama, H.; Suda, T. NLRP3 mediates NF-kappaB activation and cytokine induction in microbially induced and sterile inflammation. PLoS ONE 2015, 10, e0119179. [CrossRef]

72. Lee, K.S.; Kim, J.; Kwak, S.N.; Lee, K.S.; Lee, D.K.; Ha, K.S.; Won, M.H.; Jeoung, D.; Lee, H.; Kwon, Y.G.; et al. Functional role of NF-kappaB in expression of human endothelial nitric oxide synthase. Biochem. Biophys. Res. Commun. 2014, 448, 101-107. [CrossRef] [PubMed]

73. Aliev, G.; Smith, M.A.; de la Torre, J.C.; Perry, G. Mitochondria as a primary target for vascular hypoperfusion and oxidative stress in Alzheimer's disease. Mitochondrion 2004, 4, 649-663. [CrossRef]

74. Wilkins, H.M.; Swerdlow, R.H. Relationships between Mitochondria and Neuroinflammation: Implications for Alzheimer's Disease. Curr. Top. Med. Chem. 2016, 16, 849-857. [CrossRef] [PubMed]

75. Doll, D.N.; Hu, H.; Sun, J.; Lewis, S.E.; Simpkins, J.W.; Ren, X. Mitochondrial crisis in cerebrovascular endothelial cells opens the blood-brain barrier. Stroke 2015, 46, 1681-1689. [CrossRef] [PubMed]

76. Fossati, S.; Ghiso, J.; Rostagno, A. TRAIL death receptors DR4 and DR5 mediate cerebral microvascular endothelial cell apoptosis induced by oligomeric Alzheimer's Abeta. Cell Death Dis. 2012, 3, e321. [CrossRef]

77. Song, J.; Choi, S.M.; Whitcomb, D.J.; Kim, B.C. Adiponectin controls the apoptosis and the expression of tight junction proteins in brain endothelial cells through AdipoR1 under beta amyloid toxicity. Cell Death Dis. 2017, 8, e3102. [CrossRef]

78. Bobba, A.; Amadoro, G.; Valenti, D.; Corsetti, V.; Lassandro, R.; Atlante, A. Mitochondrial respiratory chain Complexes I and IV are impaired by beta-amyloid via direct interaction and through Complex I-dependent ROS production, respectively. Mitochondrion 2013, 13, 298-311. [CrossRef]

79. Kim, H.S.; Lee, J.H.; Lee, J.P.; Kim, E.M.; Chang, K.A.; Park, C.H.; Jeong, S.J.; Wittendorp, M.C.; Seo, J.H.; Choi, S.H.; et al. Amyloid beta peptide induces cytochrome C release from isolated mitochondria. Neuroreport 2002, 13, 1989-1993. [CrossRef]

80. Park, L.; Wang, G.; Zhou, P.; Zhou, J.; Pitstick, R.; Previti, M.L.; Younkin, L.; Younkin, S.G.; Van Nostrand, W.E.; Cho, S.; et al. Scavenger receptor CD36 is essential for the cerebrovascular oxidative stress and neurovascular dysfunction induced by amyloid-beta. Proc. Natl. Acad. Sci. USA 2011, 108, 5063-5068. [CrossRef] [PubMed]

81. Park, L.; Zhou, J.; Zhou, P.; Pistick, R.; El Jamal, S.; Younkin, L.; Pierce, J.; Arreguin, A.; Anrather, J.; Younkin, S.G.; et al. Innate immunity receptor CD36 promotes cerebral amyloid angiopathy. Proc. Natl. Acad. Sci. USA 2013, 110, 3089-3094. [CrossRef]

82. Du, H.; Guo, L.; Fang, F.; Chen, D.; Sosunov, A.A.; McKhann, G.M.; Yan, Y.; Wang, C.; Zhang, H.; Molkentin, J.D.; et al. Cyclophilin $\mathrm{D}$ deficiency attenuates mitochondrial and neuronal perturbation and ameliorates learning and memory in Alzheimer's disease. Nat. Med. 2008, 14, 1097-1105. [CrossRef] [PubMed]

83. Yin, K.J.; Lee, J.M.; Chen, S.D.; Xu, J.; Hsu, C.Y. Amyloid-beta induces Smac release via AP-1/Bim activation in cerebral endothelial cells. J. Neurosci. 2002, 22, 9764-9770. [CrossRef] [PubMed]

84. Archibald, J.M. Endosymbiosis and Eukaryotic Cell Evolution. Curr. Biol. 2015, 25, R911-R921. [CrossRef]

85. Zhong, Z.; Liang, S.; Sanchez-Lopez, E.; He, F.; Shalapour, S.; Lin, X.J.; Wong, J.; Ding, S.; Seki, E.; Schnabl, B.; et al. New mitochondrial DNA synthesis enables NLRP3 inflammasome activation. Nature 2018, 560, 198-203. [CrossRef] 
86. Yu, J.; Nagasu, H.; Murakami, T.; Hoang, H.; Broderick, L.; Hoffman, H.M.; Horng, T. Inflammasome activation leads to Caspase-1-dependent mitochondrial damage and block of mitophagy. Proc. Natl. Acad. Sci. USA 2014, 111, 15514-15519. [CrossRef]

87. Zorov, D.B.; Juhaszova, M.; Sollott, S.J. Mitochondrial reactive oxygen species (ROS) and ROS-induced ROS release. Physiol. Rev. 2014, 94, 909-950. [CrossRef]

88. Murphy, M.P. How mitochondria produce reactive oxygen species. Biochem. J. 2009, 417, 1-13. [CrossRef] [PubMed]

89. Garcia-Alloza, M.; Prada, C.; Lattarulo, C.; Fine, S.; Borrelli, L.A.; Betensky, R.; Greenberg, S.M.; Frosch, M.P.; Bacskai, B.J. Matrix metalloproteinase inhibition reduces oxidative stress associated with cerebral amyloid angiopathy in vivo in transgenic mice. J. Neurochem. 2009, 109, 1636-1647. [CrossRef]

90. Massaad, C.A.; Amin, S.K.; Hu, L.; Mei, Y.; Klann, E.; Pautler, R.G. Mitochondrial superoxide contributes to blood flow and axonal transport deficits in the Tg2576 mouse model of Alzheimer's disease. PLoS ONE 2010, 5, e10561. [CrossRef]

91. Mucke, L.; Masliah, E.; Yu, G.Q.; Mallory, M.; Rockenstein, E.M.; Tatsuno, G.; Hu, K.; Kholodenko, D.; Johnson-Wood, K.; McConlogue, L. High-level neuronal expression of abeta 1-42 in wild-type human amyloid protein precursor transgenic mice: Synaptotoxicity without plaque formation. J. Neurosci. 2000, 20, 4050-4058. [CrossRef] [PubMed]

92. Fang, F.; Lue, L.F.; Yan, S.; Xu, H.; Luddy, J.S.; Chen, D.; Walker, D.G.; Stern, D.M.; Yan, S.; Schmidt, A.M.; et al. RAGE-dependent signaling in microglia contributes to neuroinflammation, Abeta accumulation, and impaired learning/memory in a mouse model of Alzheimer's disease. FASEB J. 2010, 24, 1043-1055. [CrossRef]

93. Wan, W.; Cao, L.; Liu, L.; Zhang, C.; Kalionis, B.; Tai, X.; Li, Y.; Xia, S. Abeta(1-42) oligomer-induced leakage in an in vitro blood-brain barrier model is associated with up-regulation of RAGE and metalloproteinases, and down-regulation of tight junction scaffold proteins. J. Neurochem. 2015, 134, 382-393. [CrossRef]

94. Basta, G.; Lazzerini, G.; Del Turco, S.; Ratto, G.M.; Schmidt, A.M.; De Caterina, R. At least 2 distinct pathways generating reactive oxygen species mediate vascular cell adhesion molecule- 1 induction by advanced glycation end products. Arterioscler. Thromb. Vasc. Biol. 2005, 25, 1401-1407. [CrossRef]

95. Schmidt, A.M.; Hori, O.; Chen, J.X.; Li, J.F.; Crandall, J.; Zhang, J.; Cao, R.; Yan, S.D.; Brett, J.; Stern, D. Advanced glycation endproducts interacting with their endothelial receptor induce expression of vascular cell adhesion molecule-1 (VCAM-1) in cultured human endothelial cells and in mice. A potential mechanism for the accelerated vasculopathy of diabetes. J. Clin. Investig. 1995, 96, 1395-1403. [CrossRef]

96. Yan, S.D.; Schmidt, A.M.; Anderson, G.M.; Zhang, J.; Brett, J.; Zou, Y.S.; Pinsky, D.; Stern, D. Enhanced cellular oxidant stress by the interaction of advanced glycation end products with their receptors/binding proteins. J. Biol. Chem. 1994, $269,9889-9897$. [CrossRef]

97. Parajuli, B.; Sonobe, Y.; Horiuchi, H.; Takeuchi, H.; Mizuno, T.; Suzumura, A. Oligomeric amyloid beta induces IL-1beta processing via production of ROS: Implication in Alzheimer's disease. Cell Death Dis. 2013, 4, e975. [CrossRef]

98. Long, Y.; Liu, X.; Tan, X.Z.; Jiang, C.X.; Chen, S.W.; Liang, G.N.; He, X.M.; Wu, J.; Chen, T.; Xu, Y. ROS-induced NLRP3 inflammasome priming and activation mediate PCB 118-induced pyroptosis in endothelial cells. Ecotoxicol. Environ. Saf. 2020, 189, 109937. [CrossRef] [PubMed]

99. Nakahira, K.; Haspel, J.A.; Rathinam, V.A.; Lee, S.J.; Dolinay, T.; Lam, H.C.; Englert, J.A.; Rabinovitch, M.; Cernadas, M.; Kim, H.P.; et al. Autophagy proteins regulate innate immune responses by inhibiting the release of mitochondrial DNA mediated by the NALP3 inflammasome. Nat. Immunol. 2011, 12, 222-230. [CrossRef] [PubMed]

100. Loupatatzis, C.; Seitz, G.; Schonfeld, P.; Lang, F.; Siemen, D. Single-channel currents of the permeability transition pore from the inner mitochondrial membrane of rat liver and of a human hepatoma cell line. Cell Physiol. Biochem. 2002, 12, 269-278. [CrossRef]

101. Javadov, S.; Jang, S.; Parodi-Rullan, R.; Khuchua, Z.; Kuznetsov, A.V. Mitochondrial permeability transition in cardiac ischemiareperfusion: Whether cyclophilin D is a viable target for cardioprotection? Cell Mol. Life Sci. 2017, 74, 2795-2813. [CrossRef]

102. Parodi-Rullan, R.M.; Soto-Prado, J.; Vega-Lugo, J.; Chapa-Dubocq, X.; Diaz-Cordero, S.I.; Javadov, S. Divergent Effects of Cyclophilin-D Inhibition on the Female Rat Heart: Acute Versus Chronic Post-Myocardial Infarction. Cell Physiol. Biochem. 2018, 50, 288-303. [CrossRef] [PubMed]

103. Schinzel, A.C.; Takeuchi, O.; Huang, Z.; Fisher, J.K.; Zhou, Z.; Rubens, J.; Hetz, C.; Danial, N.N.; Moskowitz, M.A.; Korsmeyer, S.J. Cyclophilin D is a component of mitochondrial permeability transition and mediates neuronal cell death after focal cerebral ischemia. Proc. Natl. Acad. Sci. USA 2005, 102, 12005-12010. [CrossRef]

104. Song, T.; Liu, J.; Tao, X.; Deng, J.G. Protection effect of atorvastatin in cerebral ischemia-reperfusion injury rats by blocking the mitochondrial permeability transition pore. Genet. Mol. Res. 2014, 13, 10632-10642. [CrossRef] [PubMed]

105. Stockburger, C.; Eckert, S.; Eckert, G.P.; Friedland, K.; Muller, W.E. Mitochondrial Function, Dynamics, and Permeability Transition: A Complex Love Triangle as A Possible Target for the Treatment of Brain Aging and Alzheimer's Disease. J. Alzheimers Dis. 2018, 64, S455-S467. [CrossRef] [PubMed]

106. Kalani, K.; Yan, S.F.; Yan, S.S. Mitochondrial permeability transition pore: A potential drug target for neurodegeneration. Drug Discov. Today 2018, 23, 1983-1989. [CrossRef]

107. Rottenberg, H.; Hoek, J.B. The Mitochondrial Permeability Transition: Nexus of Aging, Disease and Longevity. Cells 2021, 10, 79. [CrossRef] 
108. Baines, C.P.; Kaiser, R.A.; Purcell, N.H.; Blair, N.S.; Osinska, H.; Hambleton, M.A.; Brunskill, E.W.; Sayen, M.R.; Gottlieb, R.A.; Dorn, G.W.; et al. Loss of cyclophilin D reveals a critical role for mitochondrial permeability transition in cell death. Nature 2005, 434, 658-662. [CrossRef]

109. Allam, R.; Lawlor, K.E.; Yu, E.C.; Mildenhall, A.L.; Moujalled, D.M.; Lewis, R.S.; Ke, F.; Mason, K.D.; White, M.J.; Stacey, K.J.; et al. Mitochondrial apoptosis is dispensable for NLRP3 inflammasome activation but non-apoptotic caspase-8 is required for inflammasome priming. EMBO Rep. 2014, 15, 982-990. [CrossRef]

110. Shimada, K.; Crother, T.R.; Karlin, J.; Dagvadorj, J.; Chiba, N.; Chen, S.; Ramanujan, V.K.; Wolf, A.J.; Vergnes, L.; Ojcius, D.M.; et al. Oxidized mitochondrial DNA activates the NLRP3 inflammasome during apoptosis. Immunity 2012, 36, 401-414. [CrossRef] [PubMed]

111. Clarke, S.J.; McStay, G.P.; Halestrap, A.P. Sanglifehrin A acts as a potent inhibitor of the mitochondrial permeability transition and reperfusion injury of the heart by binding to cyclophilin-D at a different site from cyclosporin A. J. Biol. Chem. 2002, 277, 34793-34799. [CrossRef]

112. Basso, E.; Fante, L.; Fowlkes, J.; Petronilli, V.; Forte, M.A.; Bernardi, P. Properties of the permeability transition pore in mitochondria devoid of Cyclophilin D. J. Biol. Chem. 2005, 280, 18558-18561. [CrossRef] [PubMed]

113. Martin, L.J.; Fancelli, D.; Wong, M.; Niedzwiecki, M.; Ballarini, M.; Plyte, S.; Chang, Q. GNX-4728, a novel small molecule drug inhibitor of mitochondrial permeability transition, is therapeutic in a mouse model of amyotrophic lateral sclerosis. Front. Cell Neurosci. 2014, 8, 433. [CrossRef] [PubMed]

114. Roy, S.; Sileikyte, J.; Neuenswander, B.; Hedrick, M.P.; Chung, T.D.; Aube, J.; Schoenen, F.J.; Forte, M.A.; Bernardi, P. NPhenylbenzamides as Potent Inhibitors of the Mitochondrial Permeability Transition Pore. ChemMedChem 2016, 11, 283-288. [CrossRef]

115. Jang, S.; Javadov, S. Association between ROS production, swelling and the respirasome integrity in cardiac mitochondria. Arch Biochem. Biophys. 2017, 630, 1-8. [CrossRef]

116. Rottenberg, H.; Hoek, J.B. The path from mitochondrial ROS to aging runs through the mitochondrial permeability transition pore. Aging Cell 2017, 16, 943-955. [CrossRef] [PubMed]

117. Yu, C.H.; Davidson, S.; Harapas, C.R.; Hilton, J.B.; Mlodzianoski, M.J.; Laohamonthonkul, P.; Louis, C.; Low, R.R.J.; Moecking, J.; De Nardo, D.; et al. TDP-43 Triggers Mitochondrial DNA Release via mPTP to Activate cGAS/STING in ALS. Cell 2020, 183, 636-649.e618. [CrossRef] [PubMed]

118. Guo, Y.; Gu, R.; Gan, D.; Hu, F.; Li, G.; Xu, G. Mitochondrial DNA drives noncanonical inflammation activation via cGAS-STING signaling pathway in retinal microvascular endothelial cells. Cell Commun. Signal. 2020, 18, 172. [CrossRef]

119. West, A.P.; Shadel, G.S. Mitochondrial DNA in innate immune responses and inflammatory pathology. Nat. Rev. Immunol. 2017, 17, 363-375. [CrossRef]

120. Farge, G.; Falkenberg, M. Organization of DNA in Mammalian Mitochondria. Int. J. Mol. Sci. 2019, 20, 2770. [CrossRef]

121. Collins, L.V.; Hajizadeh, S.; Holme, E.; Jonsson, I.M.; Tarkowski, A. Endogenously oxidized mitochondrial DNA induces in vivo and in vitro inflammatory responses. J. Leukoc. Biol. 2004, 75, 995-1000. [CrossRef] [PubMed]

122. Riley, J.S.; Tait, S.W. Mitochondrial DNA in inflammation and immunity. EMBO Rep. 2020, 21, e49799. [CrossRef] [PubMed]

123. Ablasser, A.; Chen, Z.J. cGAS in action: Expanding roles in immunity and inflammation. Science 2019, 363. [CrossRef]

124. McWhirter, S.M.; Barbalat, R.; Monroe, K.M.; Fontana, M.F.; Hyodo, M.; Joncker, N.T.; Ishii, K.J.; Akira, S.; Colonna, M.; Chen, Z.J.; et al. A host type I interferon response is induced by cytosolic sensing of the bacterial second messenger cyclic-di-GMP. J. Exp. Med. 2009, 206, 1899-1911. [CrossRef]

125. Mao, Y.; Luo, W.; Zhang, L.; Wu, W.; Yuan, L.; Xu, H.; Song, J.; Fujiwara, K.; Abe, J.I.; LeMaire, S.A.; et al. STING-IRF3 Triggers Endothelial Inflammation in Response to Free Fatty Acid-Induced Mitochondrial Damage in Diet-Induced Obesity. Arterioscler. Thromb. Vasc. Biol. 2017, 37, 920-929. [CrossRef]

126. Huang, L.S.; Hong, Z.; Wu, W.; Xiong, S.; Zhong, M.; Gao, X.; Rehman, J.; Malik, A.B. mtDNA Activates cGAS Signaling and Suppresses the YAP-Mediated Endothelial Cell Proliferation Program to Promote Inflammatory Injury. Immunity 2020, 52, 475-486.e475. [CrossRef]

127. Riley, J.S.; Quarato, G.; Cloix, C.; Lopez, J.; O’Prey, J.; Pearson, M.; Chapman, J.; Sesaki, H.; Carlin, L.M.; Passos, J.F.; et al. Mitochondrial inner membrane permeabilisation enables mtDNA release during apoptosis. EMBO J. 2018, 37, e99238. [CrossRef] [PubMed]

128. Pereira, C.A.; Carlos, D.; Ferreira, N.S.; Silva, J.F.; Zanotto, C.Z.; Zamboni, D.S.; Garcia, V.D.; Ventura, D.F.; Silva, J.S.; Tostes, R.C. Mitochondrial DNA Promotes NLRP3 Inflammasome Activation and Contributes to Endothelial Dysfunction and Inflammation in Type 1 Diabetes. Front. Physiol. 2019, 10, 1557. [CrossRef] [PubMed]

129. Scholtzova, H.; Chianchiano, P.; Pan, J.; Sun, Y.; Goni, F.; Mehta, P.D.; Wisniewski, T. Amyloid beta and Tau Alzheimer's disease related pathology is reduced by Toll-like receptor 9 stimulation. Acta Neuropathol. Commun. 2014, 2, 101. [CrossRef] [PubMed]

130. Scholtzova, H.; Kascsak, R.J.; Bates, K.A.; Boutajangout, A.; Kerr, D.J.; Meeker, H.C.; Mehta, P.D.; Spinner, D.S.; Wisniewski, T. Induction of toll-like receptor 9 signaling as a method for ameliorating Alzheimer's disease-related pathology. J. Neurosci. 2009, 29, 1846-1854. [CrossRef] [PubMed]

131. El Kebir, D.; Jozsef, L.; Pan, W.; Wang, L.; Filep, J.G. Bacterial DNA activates endothelial cells and promotes neutrophil adherence through TLR9 signaling. J. Immunol. 2009, 182, 4386-4394. [CrossRef] [PubMed] 
132. Hanke, M.L.; Kielian, T. Toll-like receptors in health and disease in the brain: Mechanisms and therapeutic potential. Clin. Sci. (Lond.) 2011, 121, 367-387. [CrossRef]

133. Iyer, S.S.; He, Q.; Janczy, J.R.; Elliott, E.I.; Zhong, Z.; Olivier, A.K.; Sadler, J.J.; Knepper-Adrian, V.; Han, R.; Qiao, L.; et al. Mitochondrial cardiolipin is required for Nlrp3 inflammasome activation. Immunity 2013, 39, 311-323. [CrossRef] [PubMed]

134. Montagne, A.; Zhao, Z.; Zlokovic, B.V. Alzheimer's disease: A matter of blood-brain barrier dysfunction? J. Exp. Med. 2017, 214, 3151-3169. [CrossRef]

135. Nation, D.A.; Sweeney, M.D.; Montagne, A.; Sagare, A.P.; D’Orazio, L.M.; Pachicano, M.; Sepehrband, F.; Nelson, A.R.; Buennagel, D.P.; Harrington, M.G.; et al. Blood-brain barrier breakdown is an early biomarker of human cognitive dysfunction. Nat. Med. 2019, 25, 270-276. [CrossRef] [PubMed]

136. Sweeney, M.D.; Kisler, K.; Montagne, A.; Toga, A.W.; Zlokovic, B.V. The role of brain vasculature in neurodegenerative disorders. Nat. Neurosci. 2018, 21, 1318-1331. [CrossRef]

137. Halliday, M.R.; Rege, S.V.; Ma, Q.; Zhao, Z.; Miller, C.A.; Winkler, E.A.; Zlokovic, B.V. Accelerated pericyte degeneration and blood-brain barrier breakdown in apolipoprotein E4 carriers with Alzheimer's disease. J. Cereb. Blood Flow Metab. 2016, 36, 216-227. [CrossRef]

138. Van Skike, C.E.; Jahrling, J.B.; Olson, A.B.; Sayre, N.L.; Hussong, S.A.; Ungvari, Z.; Lechleiter, J.D.; Galvan, V. Inhibition of mTOR protects the blood-brain barrier in models of Alzheimer's disease and vascular cognitive impairment. Am. J. Physiol. Heart Circ. Physiol. 2018, 314, H693-H703. [CrossRef]

139. Cao, Y.; Xu, H.; Zhu, Y.; Shi, M.J.; Wei, L.; Zhang, J.; Cheng, S.; Shi, Y.; Tong, H.; Kang, L.; et al. ADAMTS13 maintains cerebrovascular integrity to ameliorate Alzheimer-like pathology. PLoS Biol. 2019, 17, e3000313. [CrossRef]

140. Fossati, S.; Cam, J.; Meyerson, J.; Mezhericher, E.; Romero, I.A.; Couraud, P.O.; Weksler, B.B.; Ghiso, J.; Rostagno, A. Differential activation of mitochondrial apoptotic pathways by vasculotropic amyloid-beta variants in cells composing the cerebral vessel walls. FASEB J. 2010, 24, 229-241. [CrossRef]

141. Naveed, M.; Zhou, Q.G.; Han, F. Cerebrovascular inflammation: A critical trigger for neurovascular injury? Neurochem. Int. 2019, 126, 165-177. [CrossRef] [PubMed]

142. Zuliani, G.; Cavalieri, M.; Galvani, M.; Passaro, A.; Munari, M.R.; Bosi, C.; Zurlo, A.; Fellin, R. Markers of endothelial dysfunction in older subjects with late onset Alzheimer's disease or vascular dementia. J. Neurol. Sci. 2008, 272, 164-170. [CrossRef]

143. Rentzos, M.; Michalopoulou, M.; Nikolaou, C.; Cambouri, C.; Rombos, A.; Dimitrakopoulos, A.; Kapaki, E.; Vassilopoulos, D. Serum levels of soluble intercellular adhesion molecule-1 and soluble endothelial leukocyte adhesion molecule-1 in Alzheimer's disease. J. Geriatr. Psychiatry Neurol. 2004, 17, 225-231. [CrossRef] [PubMed]

144. Huang, C.W.; Tsai, M.H.; Chen, N.C.; Chen, W.H.; Lu, Y.T.; Lui, C.C.; Chang, Y.T.; Chang, W.N.; Chang, A.Y.; Chang, C.C. Clinical significance of circulating vascular cell adhesion molecule-1 to white matter disintegrity in Alzheimer's dementia. Thromb. Haemost. 2015, 114, 1230-1240. [CrossRef] [PubMed]

145. Kim, S.R.; Bae, Y.H.; Bae, S.K.; Choi, K.S.; Yoon, K.H.; Koo, T.H.; Jang, H.O.; Yun, I.; Kim, K.W.; Kwon, Y.G.; et al. Visfatin enhances ICAM-1 and VCAM-1 expression through ROS-dependent NF-kappaB activation in endothelial cells. Biochim. Biophys. Acta 2008, 1783, 886-895. [CrossRef]

146. Iannantuoni, F.; M de Marañon, A.; Abad-Jimenez, Z.; Canet, F.; Diaz-Pozo, P.; Lopez-Domenech, S.; Morillas, C.; Rocha, M.; Victor, V.M. Mitochondrial Alterations and Enhanced Human Leukocyte/Endothelial Cell Interactions in Type 1 Diabetes. J. Clin. Med. 2020, 9, 2155. [CrossRef] [PubMed]

147. Schweighofer, B.; Testori, J.; Sturtzel, C.; Sattler, S.; Mayer, H.; Wagner, O.; Bilban, M.; Hofer, E. The VEGF-induced transcriptional response comprises gene clusters at the crossroad of angiogenesis and inflammation. Thromb. Haemost. 2009, 102, 544-554. [CrossRef]

148. Kim, I.; Moon, S.O.; Kim, S.H.; Kim, H.J.; Koh, Y.S.; Koh, G.Y. Vascular endothelial growth factor expression of intercellular adhesion molecule 1 (ICAM-1), vascular cell adhesion molecule 1 (VCAM-1), and E-selectin through nuclear factor-kappa B activation in endothelial cells. J. Biol. Chem. 2001, 276, 7614-7620. [CrossRef]

149. Patel, S.J.; Jindal, R.; King, K.R.; Tilles, A.W.; Yarmush, M.L. The inflammatory response to double stranded DNA in endothelial cells is mediated by NFkappaB and TNFalpha. PLoS ONE 2011, 6, e19910. [CrossRef]

150. Bergstraesser, C.; Hoeger, S.; Song, H.; Ermantraut, L.; Hottenrot, M.; Czymai, T.; Schmidt, M.; Goebeler, M.; Ponelies, N.; Stich, C.; et al. Inhibition of VCAM-1 expression in endothelial cells by CORM-3: The role of the ubiquitin-proteasome system, p38, and mitochondrial respiration. Free Radic. Biol. Med. 2012, 52, 794-802. [CrossRef] [PubMed]

151. Propson, N.E.; Roy, E.R.; Litvinchuk, A.; Kohl, J.; Zheng, H. Endothelial C3a receptor mediates vascular inflammation and blood-brain barrier permeability during aging. J. Clin. Investig. 2021, 131. [CrossRef]

152. Hakkert, B.C.; Kuijpers, T.W.; Leeuwenberg, J.F.; van Mourik, J.A.; Roos, D. Neutrophil and monocyte adherence to and migration across monolayers of cytokine-activated endothelial cells: The contribution of CD18, ELAM-1, and VLA-4. Blood 1991, 78, 2721-2726. [CrossRef]

153. Elices, M.J.; Osborn, L.; Takada, Y.; Crouse, C.; Luhowskyj, S.; Hemler, M.E.; Lobb, R.R. VCAM-1 on activated endothelium interacts with the leukocyte integrin VLA-4 at a site distinct from the VLA-4/fibronectin binding site. Cell 1990, 60, 577-584. [CrossRef] 
154. Etienne-Manneville, S.; Manneville, J.B.; Adamson, P.; Wilbourn, B.; Greenwood, J.; Couraud, P.O. ICAM-1-coupled cytoskeletal rearrangements and transendothelial lymphocyte migration involve intracellular calcium signaling in brain endothelial cell lines. J. Immunol. 2000, 165, 3375-3383. [CrossRef]

155. Chavakis, T.; Bierhaus, A.; Al-Fakhri, N.; Schneider, D.; Witte, S.; Linn, T.; Nagashima, M.; Morser, J.; Arnold, B.; Preissner, K.T.; et al. The pattern recognition receptor (RAGE) is a counterreceptor for leukocyte integrins: A novel pathway for inflammatory cell recruitment. J. Exp. Med. 2003, 198, 1507-1515. [CrossRef]

156. Wang, Y.; Li, D.; Nurieva, R.; Yang, J.; Sen, M.; Carreno, R.; Lu, S.; McIntyre, B.W.; Molldrem, J.J.; Legge, G.B.; et al. LFA-1 affinity regulation is necessary for the activation and proliferation of naive T cells. J. Biol. Chem. 2009, 284, 12645-12653. [CrossRef]

157. Faraco, G.; Brea, D.; Garcia-Bonilla, L.; Wang, G.; Racchumi, G.; Chang, H.; Buendia, I.; Santisteban, M.M.; Segarra, S.G.; Koizumi, K.; et al. Dietary salt promotes neurovascular and cognitive dysfunction through a gut-initiated TH17 response. Nat. Neurosci. 2018, 21, 240-249. [CrossRef] [PubMed]

158. Kebir, H.; Kreymborg, K.; Ifergan, I.; Dodelet-Devillers, A.; Cayrol, R.; Bernard, M.; Giuliani, F.; Arbour, N.; Becher, B.; Prat, A. Human TH17 lymphocytes promote blood-brain barrier disruption and central nervous system inflammation. Nat. Med. 2007, 13, 1173-1175. [CrossRef]

159. Montagne, A.; Barnes, S.R.; Sweeney, M.D.; Halliday, M.R.; Sagare, A.P.; Zhao, Z.; Toga, A.W.; Jacobs, R.E.; Liu, C.Y.; Amezcua, L.; et al. Blood-brain barrier breakdown in the aging human hippocampus. Neuron 2015, 85, 296-302. [CrossRef] [PubMed]

160. Freeze, W.M.; Bacskai, B.J.; Frosch, M.P.; Jacobs, H.I.L.; Backes, W.H.; Greenberg, S.M.; van Veluw, S.J. Blood-Brain Barrier Leakage and Microvascular Lesions in Cerebral Amyloid Angiopathy. Stroke 2019, 50, 328-335. [CrossRef]

161. Zipser, B.D.; Johanson, C.E.; Gonzalez, L.; Berzin, T.M.; Tavares, R.; Hulette, C.M.; Vitek, M.P.; Hovanesian, V.; Stopa, E.G. Microvascular injury and blood-brain barrier leakage in Alzheimer's disease. Neurobiol. Aging 2007, 28, 977-986. [CrossRef]

162. Wisniewski, H.M.; Kozlowski, P.B. Evidence for blood-brain barrier changes in senile dementia of the Alzheimer type (SDAT). Ann. N. Y. Acad. Sci. 1982, 396, 119-129. [CrossRef]

163. Ryu, J.K.; McLarnon, J.G. Minocycline or iNOS inhibition block 3-nitrotyrosine increases and blood-brain barrier leakiness in amyloid beta-peptide-injected rat hippocampus. Exp. Neurol. 2006, 198, 552-557. [CrossRef]

164. Chen, W.; Chan, Y.; Wan, W.; Li, Y.; Zhang, C. Abeta1-42 induces cell damage via RAGE-dependent endoplasmic reticulum stress in bEnd.3 cells. Exp. Cell Res. 2018, 362, 83-89. [CrossRef]

165. Yamazaki, Y.; Shinohara, M.; Shinohara, M.; Yamazaki, A.; Murray, M.E.; Liesinger, A.M.; Heckman, M.G.; Lesser, E.R.; Parisi, J.E.; Petersen, R.C.; et al. Selective loss of cortical endothelial tight junction proteins during Alzheimer's disease progression. Brain 2019, 142, 1077-1092. [CrossRef]

166. Zhang, Q.; Zheng, M.; Betancourt, C.E.; Liu, L.; Sitikov, A.; Sladojevic, N.; Zhao, Q.; Zhang, J.H.; Liao, J.K.; Wu, R. Increase in Blood-Brain Barrier (BBB) Permeability Is Regulated by MMP3 via the ERK Signaling Pathway. Oxid. Med. Cell Longev. 2021, 2021, 6655122. [CrossRef] [PubMed]

167. Bell, R.D.; Winkler, E.A.; Singh, I.; Sagare, A.P.; Deane, R.; Wu, Z.; Holtzman, D.M.; Betsholtz, C.; Armulik, A.; Sallstrom, J.; et al. Apolipoprotein E controls cerebrovascular integrity via cyclophilin A. Nature 2012, 485, 512-516. [CrossRef] [PubMed]

168. Hernandez-Guillamon, M.; Mawhirt, S.; Fossati, S.; Blais, S.; Pares, M.; Penalba, A.; Boada, M.; Couraud, P.O.; Neubert, T.A.; Montaner, J.; et al. Matrix metalloproteinase 2 (MMP-2) degrades soluble vasculotropic amyloid-beta E22Q and L34V mutants, delaying their toxicity for human brain microvascular endothelial cells. J. Biol. Chem. 2010, 285, 27144-27158. [CrossRef]

169. Greenhalgh, A.D.; David, S.; Bennett, F.C. Immune cell regulation of glia during CNS injury and disease. Nat. Rev. Neurosci. 2020, 21, 139-152. [CrossRef] [PubMed]

170. Davalos, D.; Ryu, J.K.; Merlini, M.; Baeten, K.M.; Le Moan, N.; Petersen, M.A.; Deerinck, T.J.; Smirnoff, D.S.; Bedard, C.; Hakozaki, H.; et al. Fibrinogen-induced perivascular microglial clustering is required for the development of axonal damage in neuroinflammation. Nat. Commun. 2012, 3, 1227. [CrossRef]

171. Gouveia, A.; Bajwa, E.; Klegeris, A. Extracellular cytochrome c as an intercellular signaling molecule regulating microglial functions. Biochim. Biophys. Acta Gen. Subj. 2017, 1861, 2274-2281. [CrossRef]

172. Little, J.P.; Simtchouk, S.; Schindler, S.M.; Villanueva, E.B.; Gill, N.E.; Walker, D.G.; Wolthers, K.R.; Klegeris, A. Mitochondrial transcription factor A (Tfam) is a pro-inflammatory extracellular signaling molecule recognized by brain microglia. Mol. Cell Neurosci. 2014, 60, 88-96. [CrossRef]

173. Lautrup, S.; Lou, G.; Aman, Y.; Nilsen, H.; Tao, J.; Fang, E.F. Microglial mitophagy mitigates neuroinflammation in Alzheimer's disease. Neurochem. Int. 2019, 129, 104469. [CrossRef]

174. Joshi, A.U.; Minhas, P.S.; Liddelow, S.A.; Haileselassie, B.; Andreasson, K.I.; Dorn, G.W., 2nd; Mochly-Rosen, D. Fragmented mitochondria released from microglia trigger A1 astrocytic response and propagate inflammatory neurodegeneration. Nat. Neurosci. 2019, 22, 1635-1648. [CrossRef] [PubMed]

175. Kubli, D.A.; Gustafsson, A.B. Mitochondria and mitophagy: The yin and yang of cell death control. Circ. Res. 2012, 111, 1208-1221. [CrossRef] [PubMed]

176. Chen, G.; Kroemer, G.; Kepp, O. Mitophagy: An Emerging Role in Aging and Age-Associated Diseases. Front. Cell Dev. Biol. 2020, 8, 200. [CrossRef] [PubMed]

177. Twig, G.; Elorza, A.; Molina, A.J.; Mohamed, H.; Wikstrom, J.D.; Walzer, G.; Stiles, L.; Haigh, S.E.; Katz, S.; Las, G.; et al. Fission and selective fusion govern mitochondrial segregation and elimination by autophagy. EMBO J. 2008, 27, 433-446. [CrossRef] 
178. Batista, A.F.; Rody, T.; Forny-Germano, L.; Cerdeiro, S.; Bellio, M.; Ferreira, S.T.; Munoz, D.P.; De Felice, F.G. Interleukin-1beta mediates alterations in mitochondrial fusion/fission pro.oteins and memory impairment induced by amyloid-beta oligomers. J. Neuroinflamm. 2021, 18, 54. [CrossRef] [PubMed]

179. Jang, S.; Javadov, S. OPA1 regulates respiratory supercomplexes assembly: The role of mitochondrial swelling. Mitochondrion 2020, 51, 30-39. [CrossRef] [PubMed]

180. Ip, W.K.E.; Hoshi, N.; Shouval, D.S.; Snapper, S.; Medzhitov, R. Anti-inflammatory effect of IL-10 mediated by metabolic reprogramming of macrophages. Science 2017, 356, 513-519. [CrossRef]

181. Halle, A.; Hornung, V.; Petzold, G.C.; Stewart, C.R.; Monks, B.G.; Reinheckel, T.; Fitzgerald, K.A.; Latz, E.; Moore, K.J.; Golenbock, D.T. The NALP3 inflammasome is involved in the innate immune response to amyloid-beta. Nat. Immunol. 2008, 9, 857-865. [CrossRef]

182. Bernstein, H.G.; Kirschke, H.; Wiederanders, B.; Schmidt, D.; Rinne, A. Antigenic expression of cathepsin B in aged human brain. Brain Res. Bull. 1990, 24, 543-549. [CrossRef]

183. Ni, J.; Wu, Z.; Stoka, V.; Meng, J.; Hayashi, Y.; Peters, C.; Qing, H.; Turk, V.; Nakanishi, H. Increased expression and altered subcellular distribution of cathepsin B in microglia induce cognitive impairment through oxidative stress and inflammatory response in mice. Aging Cell 2019, 18, e12856. [CrossRef]

184. Nakanishi, H. Microglial cathepsin B as a key driver of inflammatory brain diseases and brain aging. Neural Regen. Res. 2020, 15, 25-29. [CrossRef] [PubMed]

185. Goyal, S.; Amar, S.K.; Dubey, D.; Pal, M.K.; Singh, J.; Verma, A.; Kushwaha, H.N.; Ray, R.S. Involvement of cathepsin B in mitochondrial apoptosis by p-phenylenediamine under ambient UV radiation. J. Hazard. Mater. 2015, 300, 415-425. [CrossRef] [PubMed]

186. Nagakannan, P.; Islam, M.I.; Conrad, M.; Eftekharpour, E. Cathepsin B is an executioner of ferroptosis. Biochim. Biophys. Acta Mol. Cell Res. 2021, 1868, 118928. [CrossRef]

187. Venegas, C.; Kumar, S.; Franklin, B.S.; Dierkes, T.; Brinkschulte, R.; Tejera, D.; Vieira-Saecker, A.; Schwartz, S.; Santarelli, F.; Kummer, M.P.; et al. Microglia-derived ASC specks cross-seed amyloid-beta in Alzheimer's disease. Nature 2017, 552, 355-361. [CrossRef]

188. Wang, Y.; Jin, S.; Sonobe, Y.; Cheng, Y.; Horiuchi, H.; Parajuli, B.; Kawanokuchi, J.; Mizuno, T.; Takeuchi, H.; Suzumura, A. Interleukin-1beta induces blood-brain barrier disruption by downregulating Sonic hedgehog in astrocytes. PLoS ONE 2014, 9, e110024. [CrossRef]

189. Sumi, N.; Nishioku, T.; Takata, F.; Matsumoto, J.; Watanabe, T.; Shuto, H.; Yamauchi, A.; Dohgu, S.; Kataoka, Y. Lipopolysaccharideactivated microglia induce dysfunction of the blood-brain barrier in rat microvascular endothelial cells co-cultured with microglia. Cell Mol. Neurobiol. 2010, 30, 247-253. [CrossRef] [PubMed]

190. Haruwaka, K.; Ikegami, A.; Tachibana, Y.; Ohno, N.; Konishi, H.; Hashimoto, A.; Matsumoto, M.; Kato, D.; Ono, R.; Kiyama, H.; et al. Dual microglia effects on blood brain barrier permeability induced by systemic inflammation. Nat. Commun. 2019, 10, 5816. [CrossRef]

191. Horng, S.; Therattil, A.; Moyon, S.; Gordon, A.; Kim, K.; Argaw, A.T.; Hara, Y.; Mariani, J.N.; Sawai, S.; Flodby, P.; et al. Astrocytic tight junctions control inflammatory CNS lesion pathogenesis. J. Clin. Investig. 2017, 127, 3136-3151. [CrossRef] [PubMed]

192. Scholtzova, H.; Do, E.; Dhakal, S.; Sun, Y.; Liu, S.; Mehta, P.D.; Wisniewski, T. Innate Immunity Stimulation via Toll-Like Receptor 9 Ameliorates Vascular Amyloid Pathology in Tg-SwDI Mice with Associated Cognitive Benefits. J. Neurosci. 2017, 37, 936-959. [CrossRef]

193. Patel, A.G.; Nehete, P.N.; Krivoshik, S.R.; Pei, X.; Cho, E.L.; Nehete, B.P.; Ramani, M.D.; Shao, Y.; Williams, L.E.; Wisniewski, T.; et al. Innate immunity stimulation via $\mathrm{CpG}$ oligodeoxynucleotides ameliorates Alzheimer's disease pathology in aged squirrel monkeys. Brain 2021, 144, 2146-2165. [CrossRef]

194. Aslam, M.; Ahmad, N.; Srivastava, R.; Hemmer, B. TNF-alpha induced NFkappaB signaling and p65 (RelA) overexpression repress Cldn5 promoter in mouse brain endothelial cells. Cytokine 2012, 57, 269-275. [CrossRef]

195. Lue, L.F.; Walker, D.G.; Brachova, L.; Beach, T.G.; Rogers, J.; Schmidt, A.M.; Stern, D.M.; Yan, S.D. Involvement of microglial receptor for advanced glycation endproducts (RAGE) in Alzheimer's disease: Identification of a cellular activation mechanism. Exp. Neurol 2001, 171, 29-45. [CrossRef]

196. Spampinato, S.F.; Merlo, S.; Fagone, E.; Fruciano, M.; Barbagallo, C.; Kanda, T.; Sano, Y.; Purrello, M.; Vancheri, C.; Ragusa, M.; et al. Astrocytes Modify Migration of PBMCs Induced by beta-Amyloid in a Blood-Brain Barrier in vitro Model. Front. Cell Neurosci. 2019, 13, 337. [CrossRef] [PubMed]

197. Kelso, G.F.; Porteous, C.M.; Coulter, C.V.; Hughes, G.; Porteous, W.K.; Ledgerwood, E.C.; Smith, R.A.; Murphy, M.P. Selective targeting of a redox-active ubiquinone to mitochondria within cells: Antioxidant and antiapoptotic properties. J. Biol. Chem. 2001, 276, 4588-4596. [CrossRef] [PubMed]

198. Chen, W.; Guo, C.; Huang, S.; Jia, Z.; Wang, J.; Zhong, J.; Ge, H.; Yuan, J.; Chen, T.; Liu, X.; et al. MitoQ attenuates brain damage by polarizing microglia towards the M2 phenotype through inhibition of the NLRP3 inflammasome after ICH. Pharmacol. Res. 2020, 161, 105122. [CrossRef]

199. Mukherjee, T.K.; Mishra, A.K.; Mukhopadhyay, S.; Hoidal, J.R. High concentration of antioxidants N-acetylcysteine and mitoquinone-Q induces intercellular adhesion molecule 1 and oxidative stress by increasing intracellular glutathione. J. Immunol. 2007, 178, 1835-1844. [CrossRef] [PubMed] 
200. Doughan, A.K.; Dikalov, S.I. Mitochondrial redox cycling of mitoquinone leads to superoxide production and cellular apoptosis. Antioxid. Redox Signal 2007, 9, 1825-1836. [CrossRef]

201. Zhao, K.; Luo, G.; Giannelli, S.; Szeto, H.H. Mitochondria-targeted peptide prevents mitochondrial depolarization and apoptosis induced by tert-butyl hydroperoxide in neuronal cell lines. Biochem. Pharmacol. 2005, 70, 1796-1806. [CrossRef]

202. Ding, X.W.; Robinson, M.; Li, R.; Aldhowayan, H.; Geetha, T.; Babu, J.R. Mitochondrial dysfunction and beneficial effects of mitochondria-targeted small peptide SS-31 in Diabetes Mellitus and Alzheimer's disease. Pharmacol. Res. 2021, 171, 105783. [CrossRef]

203. Tarantini, S.; Valcarcel-Ares, N.M.; Yabluchanskiy, A.; Fulop, G.A.; Hertelendy, P.; Gautam, T.; Farkas, E.; Perz, A.; Rabinovitch, P.S.; Sonntag, W.E.; et al. Treatment with the mitochondrial-targeted antioxidant peptide SS-31 rescues neurovascular coupling responses and cerebrovascular endothelial function and improves cognition in aged mice. Aging Cell 2018, 17, e12731. [CrossRef] [PubMed]

204. Mo, Y.; Deng, S.; Zhang, L.; Huang, Y.; Li, W.; Peng, Q.; Liu, Z.; Ai, Y. SS-31 reduces inflammation and oxidative stress through the inhibition of Fis1 expression in lipopolysaccharide-stimulated microglia. Biochem. Biophys. Res. Commun. 2019, 520, 171-178. [CrossRef] [PubMed]

205. Zhao, W.; Xu, Z.; Cao, J.; Fu, Q.; Wu, Y.; Zhang, X.; Long, Y.; Zhang, X.; Yang, Y.; Li, Y.; et al. Elamipretide (SS-31) improves mitochondrial dysfunction, synaptic and memory impairment induced by lipopolysaccharide in mice. J. Neuroinflamm. 2019, 16, 230. [CrossRef] [PubMed]

206. Norris, C.M.; Kadish, I.; Blalock, E.M.; Chen, K.C.; Thibault, V.; Porter, N.M.; Landfield, P.W.; Kraner, S.D. Calcineurin triggers reactive/inflammatory processes in astrocytes and is upregulated in aging and Alzheimer's models. J. Neurosci. 2005, 25, 4649-4658. [CrossRef]

207. Itani, H.A.; Dikalova, A.E.; McMaster, W.G.; Nazarewicz, R.R.; Bikineyeva, A.T.; Harrison, D.G.; Dikalov, S.I. Mitochondrial Cyclophilin D in Vascular Oxidative Stress and Hypertension. Hypertension 2016, 67, 1218-1227. [CrossRef] [PubMed]

208. Wang, X.; Zhu, S.; Pei, Z.; Drozda, M.; Stavrovskaya, I.G.; Del Signore, S.J.; Cormier, K.; Shimony, E.M.; Wang, H.; Ferrante, R.J.; et al. Inhibitors of cytochrome c release with therapeutic potential for Huntington's disease. J. Neurosci. 2008, 28, 9473-9485. [CrossRef]

209. Fossati, S.; Giannoni, P.; Solesio, M.E.; Cocklin, S.L.; Cabrera, E.; Ghiso, J.; Rostagno, A. The carbonic anhydrase inhibitor methazolamide prevents amyloid beta-induced mitochondrial dysfunction and caspase activation protecting neuronal and glial cells in vitro and in the mouse brain. Neurobiol. Dis. 2016, 86, 29-40. [CrossRef]

210. Provensi, G.; Carta, F.; Nocentini, A.; Supuran, C.T.; Casamenti, F.; Passani, M.B.; Fossati, S. A New Kid on the Block? Carbonic Anhydrases as Possible New Targets in Alzheimer's Disease. Int. J. Mol. Sci. 2019, 20, 4724. [CrossRef] [PubMed]

211. Corder, E.H.; Saunders, A.M.; Strittmatter, W.J.; Schmechel, D.E.; Gaskell, P.C.; Small, G.W.; Roses, A.D.; Haines, J.L.; Pericak-Vance, M.A. Gene dose of apolipoprotein E type 4 allele and the risk of Alzheimer's disease in late onset families. Science 1993, 261, 921-923. [CrossRef] [PubMed]

212. Hauser, P.S.; Ryan, R.O. Impact of apolipoprotein E on Alzheimer's disease. Curr. Alzheimer Res. 2013, 10, 809-817. [CrossRef] [PubMed]

213. Montagne, A.; Nation, D.A.; Sagare, A.P.; Barisano, G.; Sweeney, M.D.; Chakhoyan, A.; Pachicano, M.; Joe, E.; Nelson, A.R.; D'Orazio, L.M.; et al. APOE4 leads to blood-brain barrier dysfunction predicting cognitive decline. Nature 2020, 581, 71-76. [CrossRef]

214. Gibson, G.E.; Haroutunian, V.; Zhang, H.; Park, L.C.; Shi, Q.; Lesser, M.; Mohs, R.C.; Sheu, R.K.; Blass, J.P. Mitochondrial damage in Alzheimer's disease varies with apolipoprotein E genotype. Ann. Neurol. 2000, 48, 297-303. [CrossRef]

215. Nakamura, T.; Watanabe, A.; Fujino, T.; Hosono, T.; Michikawa, M. Apolipoprotein E4 (1-272) fragment is associated with mitochondrial proteins and affects mitochondrial function in neuronal cells. Mol. Neurodegener. 2009, 4, 35. [CrossRef] [PubMed]

216. Orr, A.L.; Kim, C.; Jimenez-Morales, D.; Newton, B.W.; Johnson, J.R.; Krogan, N.J.; Swaney, D.L.; Mahley, R.W. Neuronal Apolipoprotein E4 Expression Results in Proteome-Wide Alterations and Compromises Bioenergetic Capacity by Disrupting Mitochondrial Function. J. Alzheimers Dis. 2019, 68, 991-1011. [CrossRef] 